\title{
Leverage, Debt Maturity and Firm Investment: An Empirical Analysis
}

\author{
VIET A. DANG* \\ MANCHESTER BUSINESS SCHOOL \\ UNIVERSITY OF MANCHESTER
}

\begin{abstract}
In this paper, we examine the potential interactions of corporate financing and investment decisions in the presence of incentive problems. We develop a system-based approach to investigate the effects of growth opportunities on leverage and debt maturity as well as the effects of these financing decisions on firm investment. Using a panel of UK firms between 1996 and 2003, we find that highgrowth firms control underinvestment incentives by reducing leverage but not by shortening debt maturity. There is a positive relation between leverage and debt maturity as predicted by the liquidity risk hypothesis. Leverage has a negative effect on firm investment levels, which is consistent with the overinvestment hypothesis regarding the disciplining role of leverage for firms with limited growth opportunities.
\end{abstract}

\section{JEL classification: G32}

Keywords: Capital Structure, Leverage, Debt Maturity, Investment, Dynamic Panel Data.

* The author would like to thank an anonymous referee, Abimbola Adedeji, Dan Coffey, Robert Hudson, Cesario Mateus, Peter F. Pope (editor), Kevin T. Reilly, Norman Strong and seminar discussants and participants at Manchester Business School Finance Seminar, the Financial Management Association (FMA) European Conference 2007 and the Financial Management Association (FMA) Annual Meetings 2008, for their helpful comments and suggestions that greatly improve the paper. All remaining errors are the author's own.

Address for correspondence: Viet Anh Dang, Manchester Business School, MBS Crawford House, Booth Street West, University of Manchester, M15 6PB, United Kingdom.

Email: Vietanh.Dang@mbs.ac.uk 


\section{INTRODUCTION}

In their seminal paper, Modigliani and Miller (1958) show that in perfect capital markets, capital structure is irrelevant, and a firm's financing and investment decisions are independent. Subsequent theoretical research has relaxed the perfect capital market assumption and examined how various market frictions and imperfections give rise to potential interactions between corporate financing and investment. Myers (1977) demonstrates that in high-growth firms with risky debt, managers acting in the interest of shareholders may forgo positive-NPV projects because the payoff of these projects would at least partially accrue to debt-holders, hence leading to an underinvestment or 'debt-overhang' problem. Alternatively, Jensen (1986) and Stulz (1990) argue that in low-growth firms with large free cash flows, leverage can be used as a disciplining device because it discourages managers from overinvesting in risky projects. These agency models clearly show that the conflicts of interest among managers, shareholders and debt-holders over the exercise of investment will create potential underinvestment and overinvestment incentives, in which corporate financing and investment decisions become interrelated.

The major body of empirical research examines either corporate financing or investment in isolation. ${ }^{1}$ Based on McConnell and Servaes (1995) and Lang et al. (1996), a number of recent studies have explored the potential impact of corporate financing on investment decisions. Aivazian et al. (2005a), for example, find that leverage has a significantly negative effect on investment, which is consistent with the overinvestment hypothesis. ${ }^{2}$ In a related paper (Aivazian et al., 2005b), the same authors show that after controlling for leverage, debt maturity also has a negative impact on investment; this finding is interpreted as consistent with the underinvestment hypothesis. While these studies examine the effect of corporate financing on investment, a related strand of research investigates how investment opportunities affect corporate financing policies. Johnson (2003) and Billett et al. (2007) examine the impact of growth options on the joint choice of leverage and debt

\footnotetext{
${ }^{1}$ See, for example, Rajan and Zingales (1995) and Barclay and Smith (1995) for classic capital structure studies of leverage and debt maturity, respectively; see Fazzari et al. (1988) and Kaplan and Zingales (1997) for early investment studies.

2 See Ann et al. (2006) for a US-based study of diversified firms. See also Firth et al. (2008), who follow Aivazian et al.'s (2005a) approach and examine the impact of leverage on investment for Chinese listed firms.
} 
maturity in the presence of underinvestment incentives and the liquidity risk associated with short-term debt. ${ }^{3}$ They show that high-growth firms adopt lowleverage and/or short-term debt maturity policies to mitigate the underinvestment problem. Moreover, these policies are found to be strategic substitutes in that using short-term debt maturity attenuates the negative impact of growth opportunities on leverage (Johnson, 2003).

The aforementioned studies separately examine the effect of investment opportunities on a firm's financing decisions, and the reverse causality according to which corporate financing also affects investment decisions ex post. Hence, an important question remains as to how these financing and investment strategies interact in a dynamic framework in which growth opportunities with respect to a firm's investment set affect its joint policy of leverage and debt maturity, which in turn influences its investment activities. The objective of this paper is to empirically investigate the interdependent relations among financial leverage, debt maturity structure, growth opportunities and investment using a unified framework. Specifically, it aims to address the following questions. How is the firm's joint choice of leverage and debt maturity affected by agency problems such as underinvestment incentives? How and to what extent do potential liquidity risk problems constrain these financing decisions, especially the choice of short-term debt maturity? Do leverage and debt maturity act as strategic substitutes in controlling underinvestment incentives? Does a short-term debt maturity (or low-leverage) strategy attenuate the potential negative effect of growth opportunities on leverage (or debt maturity)? Finally, is the ex ante restructuring of leverage and debt maturity effective in controlling agency problems, and ex post, how does it affect the optimal investment strategy?

The paper contributes to the existing literature on interactions between corporate financing and investment in the following ways. First, this is one of the first studies to investigate the relation between investment opportunities and the choice of leverage and debt maturity ex ante as well as the effects of these financial policies on investment decisions ex post. We develop a system of structural equations that models financial leverage, debt maturity and firm investment simultaneously and allows us to test whether growth opportunities inversely affect leverage (or debt maturity) and

\footnotetext{
${ }^{3}$ Billett et al. (2007) further examine the effect of growth opportunities on the use of debt covenants.
} 
whether the direction of this relation is conditional on debt maturity (or leverage). ${ }^{4}$ The use of structural equations in which firm investment is modelled as an endogenous variable also facilitates an examination of the varied and complex effects of leverage and debt maturity on investment. A further advantage of the system-based model over a single-equation approach is the ability to test several predictions about leverage, debt maturity and investment while allowing for simultaneity, endogeneity and dynamics in a firm's financing and investment decisions.

In terms of methodology, our empirical analysis is conducted in a panel data setting, which controls for heterogeneity among individual firms. We employ a twostage estimation procedure in which the instrumental variable (IV) and the generalised methods of moments (GMM) estimators are adopted in the second stage to improve the consistency and efficiency of the estimates.

Finally, the system-based model developed in this paper is tested using an unbalanced panel dataset of UK firms over the period 1996-2003. Since most existing research in this area is US-based, it is of particular interest to examine corporate financing and investment behaviours in a country with a market-oriented environment similar to that of the US. Furthermore, the literature has documented a number of important differences in the corporate financing patterns of UK and US firms, which are relevant for our research questions. For example, UK firms generally have lower leverage (Rajan and Zingales, 1995; Antoniou et al., 2008) and shorter debt maturity structures (Datta et al., 2005; Marchica, 2007) compared to their US counterparts. ${ }^{5}$ The use of lower total debt and the greater reliance on debt with short-term maturities observed in UK firms are particularly relevant for analysing Myers' (1977) underinvestment hypothesis and Diamond's $(1991,1993)$ liquidity risk theory.

The paper documents several new findings. First, firms facing high growth opportunities reduce leverage, consistent with Myers' (1977) hypothesis regarding the role of a low-leverage strategy in moderating underinvestment incentives. The results, however, do not support the prediction that firms also actively shorten the maturity of

\footnotetext{
${ }^{4}$ The use of a system-based framework is consistent with recent theoretical and empirical research on the interdependence of corporate financing and investment (e.g., Elyasiani at al., 2002; Barclay et al., 2003; Dessi and Robertson, 2003; Johnson, 2003; Billett et al., 2007).

${ }^{5}$ Antoniou et al. (2008) document an average market (book) leverage ratio of 0.21 (0.18) for UK firms and 0.27 (0.27) for US firms. The proportion of short-term debt due within one year to total debt is $22 \%$ for an average US firm; see Table 1 in Datta et al. (2005). In our UK sample, short-term debt due within one year on average represents $46 \%$ of total debt; see Table A3 in Appendix 2.
} 
their debt to alleviate underinvestment, suggesting that liquidity risk constrains the use of a short-term debt maturity strategy. Unlike Johnson (2003) and Billett et al. (2007), we find that debt maturity is unaffected by growth opportunities and thus does not attenuate the negative effect of growth opportunities on leverage. Second, leverage and debt maturity exhibit a robust, positive relation, which is consistent with Diamond's (1991, 1993) liquidity risk hypothesis but is inconsistent with the argument that debt maturity and leverage are strategic substitutes for controlling underinvestment incentives. Combining these two results highlights the relative importance of the liquidity problem as compared to the underinvestment problem in determining a firm's initial choice of leverage and debt maturity. Third, there is little evidence that by actively lowering leverage to mitigate underinvestment incentives, firms will be able to make more value-increasing investments. Leverage exerts a strong, direct negative effect on the level of investment ex post possibly due to an agency cost of debt that cannot be completely alleviated. This finding is most consistent with the overinvestment hypothesis regarding the disciplining role of leverage for firms with limited growth prospects and large cash flows. Finally, while debt maturity does not have a direct negative impact on investment, firms with more (less) short-term debt are able to exploit more (fewer) valuable growth opportunities and make more (fewer) investments ex post.

The remainder of the paper is organised as follows. Section 2 develops a theoretical framework that highlights the potential interactions among leverage, debt maturity, growth opportunities and investment. Section 3 proposes a system of equations that simultaneously models leverage, debt maturity and investment. Section 4 discusses the data and methods used in the paper. Section 5 presents the empirical results and several robustness tests. Section 6 concludes.

\section{THEORETICAL FRAMEWORK}

Myers (1977) develops a principal-agent model that highlights potential interactions among growth opportunities, leverage and debt maturity. He shows that due to the agency cost of outstanding debt, the shareholder-manager coalition in control of a firm with high-growth opportunities might pass up positive-NPV projects. This underinvestment problem arises because with risky debt, the payoff of such projects at least partially accrues to the debt-holders (i.e., the principal) rather than fully accruing to the shareholders and managers (i.e., the agent). The more valuable growth options 
the firm has, the greater the degree of the underinvestment or so-called 'debt overhang' problem it faces. These underinvestment incentives can be mitigated, however, if in anticipation of valuable growth prospects, the firm lowers its leverage and/or shortens the maturity structure of its debt (Myers, 1977). ${ }^{6}$ Lowering leverage directly reduces the cost of risky 'debt overhang' and allows valuable growth opportunities to be taken. Alternatively, using short-term debt that expires before an investment project is implemented enables shareholders to gain the full benefit from the new project through renegotiation of the debt contracts, thereby mitigating the underinvestment problem.

The interactions among growth opportunities, leverage and debt maturity are affected by (i) the substitutability of leverage and debt maturity in controlling the underinvestment problem and (ii) the liquidity risk associated with short-term debt. If leverage and maturity are considered strategic substitutes, firms using short-term debt to sufficiently resolve the underinvestment problem have less incentive to lower leverage. Hence, it can be argued that shortening debt maturity helps attenuate the negative effect of growth opportunities on leverage (Johnson, 2003). ${ }^{7}$ Similarly, firms that can sufficiently control underinvestment incentives by reducing leverage will have less incentive to use short-term debt. The negative effect of growth opportunities on debt maturity can be attenuated by the initial decision to use low leverage. In sum, it is hypothesised that the impact of growth opportunities on leverage (or debt maturity) is conditional on debt maturity (or leverage).

The liquidity risk hypothesis developed by Diamond $(1991,1993)$ and Sharpe (1991) has important implications for the interactions among growth, leverage and debt maturity. Liquidity risk may impose a constraint on a firm's choice of short-term debt maturity, which may be required to control the underinvestment problem. Due to asymmetric information regarding investment, firms using short-term debt may not be able to roll over the outstanding debt contracts when their investment projects generate a negative NPV. Too much short-term debt creates significant liquidity risk,

\footnotetext{
${ }^{6}$ Debt covenants provide another vehicle to control the underinvestment problem. See Smith and Warner (1979) for a review and Billett et al. (2007) for a recent empirical study of covenants.

${ }^{7}$ Furthermore, from a trade-off perspective, a short-term debt maturity policy that reduces the agency cost of debt enables the firm to use more leverage, leading to a potential indirect, negative relation between long-term debt maturity and leverage. Note also that when high-growth firms shorten their debt maturity by issuing new short-term debt, the total debt ratio tends to increase, resulting in a mechanical, positive relation between growth opportunities and leverage.
} 
thereby increasing bankruptcy costs and constraining debt capacity (Childs et al., 2005). Thus, the economic relation between growth opportunities and debt maturity is determined by the trade-off between the decreased agency cost (i.e., underinvestment) and increased bankruptcy cost (i.e., liquidity risk) of short-term debt. When firms have the ability to moderate liquidity risk, mitigating incentive problems are of firstorder importance so that a short-term debt maturity strategy can be adopted to resolve the underinvestment problem. When firms have less financial flexibility, they will tend to lower their leverage ratio but still may not choose to shorten the maturity of their debt because of liquidity constraints (Childs et al., 2005). ${ }^{8}$

The implications of this liquidity risk argument are twofold. In the presence of significant liquidity risk, a low-leverage strategy may be preferred to a short-term debt maturity strategy as a solution to the underinvestment problem. While growth opportunities are predicted to exert a strong negative impact on leverage, the effect of growth on debt maturity reflects the trade-off between the benefit of using short-term debt to mitigate underinvestment incentives and the cost of the associated liquidity risk. Second, the liquidity risk hypothesis suggests a positive, direct relation between leverage and long-term debt maturity. Firms that maintain short-term (long-term) debt maturity will face high (low) liquidity risk and will have an incentive to reduce (increase) leverage. In sum, the sign of the relation between leverage and debt maturity is determined by the net effect of the reduced underinvestment problem (i.e., a substitution effect) and increased liquidity risk (i.e., a complementary effect).

Myers' (1977) underinvestment hypothesis also provides important empirical implications for the interactions among leverage, debt maturity, and investment outcomes ex post. ${ }^{9}$ The discussion above demonstrates how lowering leverage and/or shortening debt maturity can help mitigate underinvestment incentives. The argument follows that if in anticipation of high-growth options, firms can resolve the underinvestment problem completely by ex ante restructuring of leverage and debt maturity, they will be able to exploit more growth opportunities ex post. In particular, a low-leverage and/or a short-term debt maturity strategy allow more growth options

\footnotetext{
${ }^{8}$ In an extreme case in which liquidation probabilities are too high, firms may have to lengthen the maturity of their debt though this strategy may lead to a more severe underinvestment problem.

9 Jensen's (1986) overinvestment problem also implies a negative relation between leverage and firm investment as briefly discussed in the Introduction. This issue will be examined in detail in Section 5(iv).
} 
to be taken, resulting in a higher level of investment. Lowering leverage and/or shortening debt maturity are thus predicted to magnify the positive effect of growth opportunities on investment.

This prediction, however, depends on the assumptions that growth opportunities are fully recognised and that underinvestment incentives can be controlled completely through the ex ante restructuring of leverage and debt maturity (Aivazian et al., 2005a). A violation of any of these two assumptions will give rise to a negative effect of leverage and/or debt maturity on investment. For example, it can be argued that it is costly to implement these strategic financing adjustments. Specifically, if renegotiation and transaction costs incurred to repurchase debt or to shorten the maturity of debt outweigh the benefit of attenuated underinvestment, firms will be better off not adjusting leverage and debt maturity. ${ }^{10}$ Similarly, when the cost of the liquidity risk associated with short-term debt is greater than the reduced cost of underinvestment problems, firms will have less incentive to shorten their debt maturity. Overall, transaction costs and liquidity risk may constrain firms from fully adjusting their leverage and debt maturity structure, resulting in underinvestment ex post.

Furthermore, when growth opportunities are not anticipated sufficiently early and completely, there is even less scope for alleviating underinvestment incentives (Aivazian et al., 2005a). Renegotiation with the debt-holders will have to be completed quickly, thus increasing the bargaining and transaction costs faced by the firm. These increased costs will further prevent the firm from adjusting their leverage and debt maturity. Hence, firms with a high leverage ratio and/or a long-term debt maturity ex ante will be likely to forgo valuable growth opportunities, implying a negative effect of leverage and debt maturity on their ex post investment levels.

\section{ECONOMETRIC MODELS}

To test the theoretical framework proposed in Section 2, we develop a system-based model consisting of three structural equations, thus simultaneously modelling leverage, debt maturity and firm investment.

\footnotetext{
${ }^{10}$ See also Leary and Roberts (2005) for some recent evidence on the costly adjustment of leverage.
} 


\section{(i) Leverage Equation}

We specify the leverage equation as a dynamic partial adjustment model (e.g., Ozkan, 2001; Flannery and Rangan, 2006) and further augment it by including debt maturity and its interaction term with growth opportunities as follows:

$$
\begin{aligned}
L E V_{i, t}=\alpha_{0} & +\delta_{L E V} L E V_{i, t-1}+\alpha_{1} M A T_{i, t}+\alpha_{2} G T H_{i, t}+\alpha_{3} G T H \times M A T_{i, t}+\mathbf{x}_{\mathbf{i}, \mathbf{t}}^{\mathbf{L E V}} \boldsymbol{\beta}^{\mathbf{L E V}} \\
& +\mu_{i}+u_{i, t},
\end{aligned}
$$

where $L E V_{i, t}, M A T_{i, t}$ and $G T H_{i, t}$ denote market leverage, debt maturity (measured by the ratio of long-term debt due in more than one year to total debt) and growth opportunities (market-to-book) at time $t$, respectively. ${ }^{11} \mathbf{x}_{\mathbf{i}, \mathbf{t}}^{\mathbf{L E V}}$ is a $1 \times k$ vector of the (k) determining factors of leverage; $\boldsymbol{\beta}^{\mathbf{L E V}}$ is a $k \times 1$ vector of the coefficients; and $\mu_{i}$ represents the time-invariant unobservable firm and/or industry-specific fixed effects, which capture firm and industry characteristics. ${ }^{12} u_{i t}$ is the error term such that $u_{i t} \sim \operatorname{iid}\left(0, \sigma_{u}^{2}\right)$.

Equation (1) has a number of noteworthy features. First, a lagged value of leverage is included to control for dynamic adjustment towards target leverage as predicted by the trade-off theory of capital structure (Ozkan, 2001; Flannery and Rangan, 2006). The speed of adjustment, as represented by $\left(1-\delta_{L E V}\right)$, is expected to be significantly positive.

The model specification also includes debt maturity and growth opportunities as explanatory variables; their respective coefficient estimates capture the direct effects on leverage. Myers' (1977) underinvestment hypothesis predicts a negative coefficient on growth opportunities. As discussed in Section 2, the liquidity risk and underinvestment hypotheses have conflicting predictions regarding the relation between debt maturity and leverage. Hence, the net effect of debt maturity on

\footnotetext{
${ }^{11}$ Johnson (2003) measures debt maturity by using the ratio of short-term to total debt. For UK firms, however, such a measure may proxy for creditor identity given the relatively higher proportion of bank debt in short-term debt (e.g., Marchica, 2007). Thus, the long-term debt maturity measure is considered a more appropriate measure of debt maturity in the UK context. Empirically, the use of this measure is consistent with previous research; see, for example, Antoniou et al. (2006).

${ }^{12}$ In a robustness test, we include firm-invariant time-specific effects, which control for potential macroeconomic shocks, changes in the state of the economy, interest rates and prices, accounting standards and other regulations, and so on. Unreported results are qualitatively similar for the leverage equation, but are less satisfactory for the debt maturity and investment equations.
} 
leverage will be determined empirically by the trade-off between the cost of the liquidity problem and that of underinvestment incentives.

Furthermore, we follow Johnson (2003) and use an interaction term between debt maturity and growth opportunities in order to test whether debt maturity attenuates the expected negative effect of growth opportunities on leverage. In Equation (1), the effect of growth opportunities on leverage is given by $\partial L E V / \partial G T H=\alpha_{2}+\alpha_{3} M A T$, where $\alpha_{2}$ is the stand-alone coefficient on growth opportunities, and $\alpha_{3}$ the coefficient on growth interacted with debt maturity. The first term represents a potential direct negative effect of growth opportunities on leverage, while the second term represents an indirect attenuation effect of short-term debt maturity. If the coefficient on the interaction term, $\alpha_{3}$, is negative, then the shorter the firm's debt maturity is, the smaller the (inverse) impact of growth on leverage will be. For firms that can sufficiently control the underinvestment problem through a short-term debt maturity strategy, the negative effect of growth opportunities on leverage can theoretically be eliminated (Johnson, 2003).

Finally, the vector of control variables, $\mathbf{x}_{\mathbf{i}, \mathbf{t}}^{\mathbf{L E V}}$, includes four conventional determinants of leverage drawn from previous research (Titman and Wessels, 1988; Ragan and Zingales, 1995), including non-debt tax shields, tangibility, profitability and firm size; see Table A1 in Appendix 1 for variable definitions. ${ }^{13}$ Non-debt tax shields are a substitute for the tax benefits of debt, and so firms with high non-debt tax shields are predicted to have less debt (DeAngelo and Masulis, 1980). The collateral value of assets (i.e., tangibility) can be used as a security to avoid the asset substitution effect and to reduce the agency costs of debt; hence, firms with high tangibility should carry more debt (see Frank and Goyal, 2007). The relation between profitability and leverage is negative according to the pecking order theory (Myers, 1984; Myers and Majluf, 1984), but it can also be positive as predicted by the tradeoff framework (Modigliani and Miller, 1963; Jensen, 1986). Firm size is predicted to exert a positive effect on leverage because large firms face low agency, bankruptcy and transaction costs and are less vulnerable to asymmetric information and adverse

\footnotetext{
${ }^{13}$ In robustness tests, we use additional control variables such as earnings volatility, firm quality and the tax ratio. The unreported estimation results are qualitatively similar to those presented here.
} 
selection; they hence have easier access to financial markets (see Frank and Goyal, 2007).

\section{(ii) Debt Maturity Equation}

Consistent with the model specification for the leverage equation, the estimated model for debt maturity is specified as follows:

$$
\begin{aligned}
M A T_{i, t}=\gamma_{0} & +\delta_{M A T} M A T_{i, t-1}+\gamma_{1} L E V_{i, t}+\gamma_{2} G T H_{i, t}+\gamma_{3} G T H \times L E V_{i, t}+\mathbf{x}_{\mathbf{i}, \mathbf{t}}^{\mathbf{M A T}} \boldsymbol{\beta}^{\mathrm{MAT}} \\
& +\pi_{i}+v_{i, t},
\end{aligned}
$$

where $\mathbf{x}_{\mathbf{i}, \mathbf{t}}^{\mathrm{MAT}}$ represents a $1 \times l$ vector of the $l$ determining factors of debt maturity; $\boldsymbol{\beta}^{\text {MAT }}$ denotes a $l \times 1$ vector of the coefficients; $\pi_{i}$ is the unobservable firm and/or industry-specific fixed effects; and $v_{i t}$ is the error term such that $v_{i t} \sim \operatorname{iid}\left(0, \sigma_{v}^{2}\right)$.

In Equation (2), we extend previous empirical models on debt maturity (Barclay and Smith, 1995; Ozkan, 2000) in several dimensions to capture potential interactions among leverage, debt maturity and growth opportunities. As in the leverage equation, lagged maturity is included to control for the dynamics of debt maturity. Recent theoretical and empirical findings suggest that firms have an optimal debt maturity structure (Brick and Ravid, 1985; Kane et al., 1985; Jun and Jen, 2003) towards which they seek to adjust in the long run (Ozkan, 2000; Antoniou et al., 2006). ${ }^{14}$ In Equation (2), leverage and growth opportunities enter as right-hand-side regressors; their respective coefficients capture the direct effects on debt maturity. The coefficient estimate of leverage is expected to be consistent with that of debt maturity in the leverage equation in terms of both sign and magnitude.

We also include an interaction term between growth opportunities and leverage to capture a potential attenuation effect of leverage on the hypothesised negative relation between growth and debt maturity. The net effect of growth opportunities on debt maturity is given by $\partial M A T / \partial G T H=\gamma_{2}+\gamma_{3} L E V$, where $\gamma_{2}$ and $\gamma_{3}$ are the coefficients on growth and growth interacted with leverage, respectively. The sign of the coefficient on the interaction term, $\gamma_{3}$, indicates whether leverage attenuates a potential negative effect of growth opportunities on debt

\footnotetext{
${ }^{14}$ Lewis (1990) shows, however, that debt maturity structure is irrelevant in a multi-period financing framework, in which capital structure and debt maturity decisions are made simultaneously and the only market imperfection is taxation.
} 
maturity. If firms can reduce leverage to alleviate the underinvestment problem, they may have less incentive to shorten their debt maturity structures; hence the coefficient $\gamma_{3}$ should have a negative sign. Furthermore, if the underinvestment problem can be controlled sufficiently through a low-leverage policy, firms may not even choose to shorten the maturity of their debt, implying no economic relation between growth opportunities and debt maturity. ${ }^{15}$

Following previous empirical research (e.g., Antoniou et al., 2006), the vector of regressors, $\mathbf{x}_{\mathbf{i}, \mathbf{t}}^{\mathrm{MAT}}$, includes six determinants of debt maturity, namely, firm size, asset maturity structure, tax ratio, term structure of interest rates, volatility and firm quality; see Table A1 in Appendix 1 for variable definitions. Larger firms with lower asymmetric information and agency costs have easier access to long-term debt markets, implying a positive relation between debt maturity and firm size (Antoniou et al., 2006). Theoretical and empirical research shows that firms tend to match their debt maturities to their asset maturities (Hart and Moore, 1994; Stohs and Mauer, 1996), suggesting a positive relation between these two variables. Tax-based models show that debt maturity decreases with the tax advantage of debt (Kane et al., 1995) but increases with the slope of the yield curve (Brick and Ravid, 1985). Volatility is predicted to have a negative effect on optimal debt maturity because firms with highly volatile value face high bankruptcy costs and are expected to use more long-term debt than short-term debt (Kane et al., 1985). The signalling hypothesis suggests that firms with high asymmetric information choose to signal their good quality by issuing short-term debt (Flannery, 1986), implying a negative relation between debt maturity and firm quality.

\section{(iii) Investment Equation}

Existing empirical research on the interactions of corporate financing and investment generally estimates a Tobin's $q$ model of investment (Lang et al., 1996; Aivazian et al., 2005a; 2005b). ${ }^{16}$ Therefore, we employ this model specification here to facilitate

\footnotetext{
${ }^{15}$ Note, however, that growth opportunities may also have an insignificant impact on debt maturity if high liquidity cost outweighs the benefit of short-term debt in controlling underinvestment incentives.

${ }^{16}$ While the Tobin's $q$ model is widely used in the literature, it is also subject to a number of criticisms. See, for example, Hayashi (1982) and Erickson and Whited (2000). See also Goergen and Renneboog (2001) for a survey of four classes of investment models, including the neoclassical model, the sales accelerator model, the Tobin's Q model and the Euler equation model. See Bond et al. (2003) and Guariglia (2008) for recent studies using error correction models.
} 
comparisons with previous evidence. To control for the effect of corporate financing on investment, we include leverage and debt maturity (Aivazian et al., 2005a, 2005b; Hovakimian, 2009) as well as their respective interaction terms with growth opportunities as explanatory variables as follows:

$$
\begin{aligned}
I N V_{i, t}=\varphi_{0}+ & \delta_{I N V} I N V_{i, t-1}+\varphi_{1} L E V_{i, t-1}+\varphi_{2} M A T_{i, t-1}+\varphi_{3} G T H_{i, t-1} \\
& +\varphi_{4} G T H \times L E V_{i, t-1}+\varphi_{5} G T H \times M A T_{i, t-1}+\varphi_{6} C F_{i, t-1}+\phi_{i}+w_{i, t},
\end{aligned}
$$

where $I N V_{i, t}$ is firm investment, measured by capital expenditures less depreciation divided by total assets at time $t$ (Aivazian et al., 2005a, 2005b); $C F_{i, t-1}$ represents cash flow at $t-1 ; \phi_{i}$ is the unobservable firm and/or industry-specific fixed effect; and $w_{i, t}$ the error term such that $w_{i, t} \sim \operatorname{iid}\left(0, \sigma_{w}^{2}\right)$.

Growth opportunities are proxied by Tobin's $q$, which in turn is measured by the market value of the firm's total assets divided by the book value of these assets. In the Tobin's $q$ model, the expectation of future profitability is captured by forwardlooking stock market valuation, and so absent severe financial constraints, firms with high growth options will be able to make more investments. This implies a positive relation between lagged growth opportunities and current investment expenditures. Cash flow is included to control for the firm's financial constraints (Fazzari et al., 1988). The coefficient on this variable represents the degree of cash flow sensitivity to investment, which equals zero if firms are not financially constrained but is significantly positive if firms face some form of financial constraint. ${ }^{17}$ Lagged investment is included as an explanatory variable to capture a potential accelerator effect of investment (Aivazian et al., 2005a, 2005b).

In Equation (3), we include leverage and debt maturity to control for the potential interactions of financing and investment decisions (Aivazian et al., 2005a, 2005b). ${ }^{18}$ The preceding discussion suggests that in the presence of unanticipated growth prospects and/or high contracting costs, the initial joint policy of leverage and

\footnotetext{
17 This interpretation is the subject of a heated debate in the investment literature (e.g., Kaplan and Zingales, 1997; Cleary, 1999; Fazzari et al., 2000; Kaplan and Zingales, 2000; Cleary, 2006; Cleary et al., 2007). Nevertheless, this issue is not the main focus of this paper.

${ }^{18}$ Hennessy (2004) estimates a similar model and includes a debt overhang correction term (i.e., the ratio of bondholders' recovery in default over capital) to capture the effect of underinvestment incentives.
} 
debt maturity may inversely affect the level of investment ex post. In particular, highleverage and/or long-term debt maturity curtails investment, suggesting negative coefficients on both leverage and debt maturity.

Finally, our investment equation includes two interaction terms, one between growth opportunities and leverage and the other between growth opportunities and debt maturity. Using these two interaction terms facilitates an assessment of the indirect effect of growth opportunities on investment, conditional on the initial choice of leverage and debt maturity. The effect of growth opportunities on investment is given by $\partial I N V_{i, t} / \partial G R O W T H_{i, t-1}=\varphi_{3}+\varphi_{4} L E V_{i, t-1}+\varphi_{5} M A T_{i, t-1}$, where $\varphi_{3}$ is the coefficient on growth opportunities (i.e., the stand-alone effect), and $\varphi_{4}$ and $\varphi_{5}$ are the coefficients on the two interaction terms. As discussed in Section 2, firms that lower leverage and/or shorten the maturity of their debt ex ante are expected to make more investments ex post. In contrast, firms that maintain high leverage and/or longterm debt maturity are less likely to exploit valuable growth opportunities; hence, the coefficients on the two interaction terms should have a negative sign.

\section{METHODOLOGY AND DATA}

\section{(i) Methodology}

The model developed in the previous section consists of three equations in which leverage, debt maturity and investment are treated as endogenous. ${ }^{19}$ Estimation of each equation separately will result in biased and inconsistent estimates due to a simultaneous-equations bias. To deal with this problem, we adopt a two-stage estimation procedure that involves replacing the endogenous variables with their predicted values from the reduced-form regressions on the exogenous variables (Wooldridge, 2002). In what follows, we show in detail how estimation is performed.

\footnotetext{
${ }^{19}$ Although firm investment is not included as a regressor in the leverage and debt maturity equations, it is the dependent variable in the investment equation and is treated as an endogenous variable in the system. Note further that estimating the investment equation independently and separately from the system is likely to lead to inconsistent and biased results due to the endogeneity of the two regressors, namely, leverage and debt maturity (Lang et al., 1996; Aivazian et al., 2005a, 2005b). The same argument applies to the leverage and debt maturity equations. Hence, while we discuss the three equations separately in Section 3, it is essential to model and estimate them under the proposed systembased framework.
} 
In order to adopt the two-stage approach, it is necessary to identify the instruments for the endogenous variables in our model. ${ }^{20}$ In the leverage equation, the instruments for debt maturity can be selected from five exogenous variables available in the debt maturity and investment equations, including asset maturity, tax ratio, term structure, volatility, firm quality and cash flow. Since tax ratio, volatility, firm quality and cash flow are potentially correlated with leverage (Harris and Raviv, 1991; Frank and Goyal, 2009), only asset maturity and term structure are chosen as the instruments for debt maturity (Elyasiani et al., 2002; Aivazian et al., 2005a, 2005b). In the debt maturity equation, leverage is instrumented by non-debt tax shields, tangibility and profitability, which are not theoretically related to debt maturity structure (Johnson, 2003). In the investment equation, the instruments for lagged debt maturity and lagged leverage are the same as those used in the first two equations, except that here lagged values are used instead of values in levels.

Conventional techniques such as the two-stage least squares estimators (2SLS) employ the OLS or fixed-effects (FE) estimators in the second stage of estimation. Although this approach overcomes the simultaneity problem, applying it to our model will produce biased and inconsistent estimates because all three equations in the system are dynamic panel models in which the lagged dependent variables are correlated with the individual effects. For example, there is a potential correlation between $L E V_{i, t-1}$ and $\mu_{i}$ in Equation (1). We address this problem by adopting the IV and GMM estimators in the second stage of estimation.

The IV approach involves transforming the dynamic equations by firstdifferencing them to eliminate the individual effects and their potential correlation with the lagged values of the dependent variables (Anderson and Hsiao, 1982). Applying this technique to the proposed system yields the following transformed equations:

$$
\begin{aligned}
\Delta L E V_{i, t}= & \delta_{L E V} \Delta L E V_{i, t-1}+\alpha_{1} \Delta M A T_{i, t}+\alpha_{2} \Delta G T H_{i, t}+\alpha_{3} \Delta G T H \times M A T_{i, t} \\
& +\Delta \mathbf{x}_{\mathbf{i}, \mathbf{t}}^{\mathbf{L E V}} \boldsymbol{\beta}^{\mathbf{L E V}}+\Delta u_{i, t}, \\
\Delta M A T_{i, t}= & \delta_{M A T} \Delta M A T_{i, t-1}+\gamma_{1} \Delta L E V_{i, t}+\gamma_{2} \Delta G T H_{i, t}+\gamma_{3} \Delta G T H \times L E V_{i, t}
\end{aligned}
$$

\footnotetext{
${ }^{20}$ Since the number of exogenous variables excluded from Equations (1), (2) and (3) is larger than the number of endogenous variables included in those equations, the identification condition is satisfied.
} 


$$
\begin{gathered}
+\Delta \mathbf{x}_{\mathbf{i}, \mathbf{t}}^{\mathrm{MAT}} \boldsymbol{\beta}^{\mathrm{MAT}}+\Delta v_{i, t}, \\
\Delta I N V_{i, t}=\delta_{I N V} \Delta I N V_{i, t-1}+\varphi_{1} \Delta L E V_{i, t-1}+\varphi_{2} \Delta M A T_{i, t-1}+\varphi_{3} \Delta G T H_{i, t-1} \\
+\varphi_{4} \Delta G T H \times L E V_{i, t-1}+\varphi_{5} \Delta G T H \times M A T_{i, t-1}+\varphi_{6} \Delta C F_{i, t-1}+\Delta w_{i, t} .
\end{gathered}
$$

It is readily seen that the first-lagged dependent variable in first differences can be instrumented by the second-lagged value in levels, e.g., $\Delta L E V_{i, t-1}$ as instrumented by $L E V_{i, t-2}$ in Equation (4). Similarly, $\Delta M A T_{i, t-1}$ and $\Delta I N V_{i, t-1}$ can be instrumented by $M A T_{i, t-2}$ and $I N V_{i, t-2}$ in Equations (5) and (6), respectively. This IV-type estimator is consistent because the second-lagged value in levels (e.g., $L E V_{i, t-2}$ ) is related to the first-lagged value in differences (e.g., $\Delta L E V_{i, t-1}$ ) but is not related to the error term in first differences (e.g., $\Delta u_{i t}$ ).

To improve the efficiency of the IV estimation, we consider the two-step GMM estimator, which further exploits all linear restrictions under the assumption of no serial correlation (Arellano and Bond, 1991). ${ }^{21}$ This approach also involves firstdifferencing the dynamic equations as outlined above and then creating a matrix of instruments by using the orthogonality conditions between the lagged values of the dependent variable and the error term. For the purpose of illustration, the GMM instruments for $\triangle M A T_{i, t-1}$ in the transformed debt maturity equation, given by Equation (5) include a set of $t-2$ elements $\left(M A T_{i, t-2}, M A T_{i, t-3}, \ldots, M A T_{i 1}\right)$. This GMM approach is essentially a generalisation of the IV method that only uses the secondlagged value in levels as instruments (e.g., $\left.M A T_{i, t-2}\right){ }^{22}$

\footnotetext{
${ }^{21}$ It is well-established in the econometrics literature that the two-step GMM estimator is more efficient than the one-step approach because it is robust to any form of heteroscedasticity and crosscorrelation. Moreover, we apply Windmeijer's (2005) small-sample correction to the two-step GMM standard errors, which are potentially downward-biased, especially when the number of instruments is large.

${ }^{22}$ In a robustness test, we employ Blundell and Bond's (1998) system GMM estimator (SYSGMM), which arguably further improves the efficiency of Arellano and Bond's (1991) GMM approach by using additional instruments in the original level equations. However, the unreported SYSGMM estimation results are not satisfactory for the debt maturity and investment equations due to the problem of weak instruments and serial correlation, as indicated by the Sargan and AR(2) tests.
} 
(ii) Data

We examine an unbalanced panel dataset of UK firms that was collected from the Datastream database. We impose four restrictions on the data. First, firms operating in financial sectors (i.e., banks, insurance and life assurance companies and investment trusts) and in utilities sectors (i.e., electricity, water and gas distribution) are excluded because they are subject to different regulatory accounting considerations. Second, in order to use the IV and GMM estimators that require the use of lags, only firms that have five years or more of observations are retained. Third, observations that have missing data for the variables of interest are removed. Fourth, we follow the literature and winsorise all variables at the $1^{\text {st }}$ and $99^{\text {th }}$ percentiles to alleviate the effect of outliers (Cleary, 1999; Aivazian et al., 2005a; 2005b). The final panel data set consists of 678 firms with 4,170 firm-year observations from 1996 to 2003. Appendix 2 summarises the structure of the unbalanced panel data. Table 1 provides descriptive statistics of the variables.

\section{EMPIRICAL RESULTS}

In this section, we first summarise and discuss the empirical results. We then examine the robustness of the evidence for the underinvestment hypothesis by taking into consideration the overinvestment problem, which has similar implications for the interactions among leverage, growth opportunities and investment. We conclude with a discussion of several additional robustness tests of the main findings.

\section{(i) Results for the Leverage Equation}

Table 2 presents the two-stage regression results for the leverage equation based on Equation (1). Columns (1), (3) and (5) use the IV estimator, while columns (2), (4) and (6) adopt the two-step GMM estimator. The first two columns report the results for the baseline specifications. The next four columns report the results for the restricted models in which growth and its interaction term with debt maturity are omitted. Overall, the results for all six models are appropriate, with most of the coefficients on the control variables being significant and having the expected signs. While the GMM estimator employs more instruments and is potentially more efficient than the IV approach, both the IV and GMM estimates are broadly similar in terms of their sign and magnitude. Moreover, the Sargan and AR(2) tests suggest that all six models are generally satisfactory. The coefficient on lagged leverage is significantly 
positive at the $1 \%$ significance level, which supports the choice of a dynamic specification for modelling leverage adjustment and is consistent with capital structure trade-off theory. The magnitude of this coefficient is less than 0.30 , suggesting that UK firms have a rapid speed of adjustment, with more than $70 \%$ of the deviation from target leverage being closed within a year.

The coefficient on debt maturity is found to be significantly positive at the $5 \%$ significance level, except in model (5). This finding is consistent with Elyasiani (2002), Barclay et al. (2003) and Johnson (2003) and supports the liquidity risk hypothesis that predicts a direct positive relation between debt maturity and leverage (Diamond, 1991, 1993; Childs et al., 2005). Firms with a short-term debt maturity structure face a potential liquidity risk problem, which can be mitigated by adopting a low-leverage policy. In contrast, firms with long-term debt face a less severe liquidity risk and will be able to use more leverage.

The results for the interaction term between debt maturity and growth opportunities are mixed. In the baseline specifications in columns (1) and (2), this interaction term is negative but insignificant. In columns (5) and (6), growth is excluded to eliminate any potential correlation with its interaction with debt maturity, and the results show that this interaction term has a significantly negative effect on leverage at the $1 \%$ significance level. Overall, these results suggest that for firms with high growth, the overall positive relation between maturity and leverage may become weaker. Theoretically, the direction and magnitude of this relation is determined by the trade-off between the cost of the liquidity problem and that of underinvestment. While firms with long-term debt maturity face low liquidity risk and have incentives to increase leverage, those facing particularly high growth prospects may only moderately raise leverage. That is, using too much leverage might expose highgrowth firms to underinvestment incentives, which are more likely to arise in highgrowth states. In contrast, for low-growth firms the underinvestment problem is less severe; as a result, liquidity risk considerations dominate, suggesting a strong positive relation between leverage and debt maturity.

Furthermore, the coefficient on the interaction term is relatively small in magnitude as compared to the coefficient on maturity. The highest (smallest) coefficient estimate of debt maturity is $0.562(0.329)$, while that of the interaction term is $-0.043(-0.012)$. Thus, the highest (smallest) total effect of debt maturity on leverage at the mean growth of 1.795 is equal to 0.485 (0.307). This total effect 
remains positive at the highest growth value. Therefore, even when considerable growth opportunities are available, the partial derivative of leverage with respect to debt maturity is always positive. This finding shows that the cost of the liquidity risk problem outweighs that of underinvestment, suggesting that liquidity risk considerations play a more important role in determining a firm's financial policy.

The results in columns (1), (2), (3) and (4) provide consistent evidence that growth opportunities have a negative impact on leverage at least at the 5\% significance level. ${ }^{23}$ This finding is in line with prior empirical evidence (Homaifar et al., 1994; Rajan and Zingales, 1995; Ozkan, 2001; Johnson, 2003) and provides strong support for the underinvestment hypothesis (Myers, 1977).

The overall effect of growth opportunities on leverage is also influenced by an indirect effect of growth on leverage, which is captured by the interaction term between growth and debt maturity. In the baseline models in columns (1) and (2), the coefficient on this interaction term is negative but insignificant. This finding provides little evidence for the attenuation effect of debt maturity and is inconsistent with Johnson (2003). Irrespective of the choice of debt maturity, firms adopt a lowleverage strategy to control underinvestment problems. In columns (5) and (6), the interaction term between growth and debt maturity has a negative impact on leverage at the $1 \%$ significance level. Caution should be taken in interpreting this finding, as it may be driven by the inverse relation between leverage and growth opportunities, which is omitted in these models. Furthermore, a potential attenuation effect of debt maturity should only arise when short-term debt is used actively to alleviate the underinvestment problem. In the next subsection, we interpret the results for the debt maturity equation and provide further insights to the present discussion.

\section{(ii) Results for the Debt Maturity Equation}

Table 3 presents the results for the debt maturity equation. As in Table 2, we report the IV estimation results in columns (1), (3) and (5) and the two-step GMM results in columns (2), (4) and (6). The first two columns contain the results for the baseline specifications based on Equation (2). In the last four columns, we present the results for alternative specifications of debt maturity in which growth opportunities and its interaction with leverage are excluded.

\footnotetext{
${ }^{23}$ In unreported tests, we obtain qualitatively similar results when estimating the static and dynamic models of leverage in one stage and either excluding debt maturity or assuming it is exogenous.
} 
A general examination reveals that the results for the debt maturity equation are appropriate but are less significant than those reported in Table 2 for the leverage equation. $^{24}$ Furthermore, the theoretically more efficient GMM estimations yield better results than the IV estimations in terms of the significance of the coefficients. Hence, the following analysis focuses on the GMM estimation results. Regarding the control variables, only firm size and tax ratio are significant at the $1 \%$ significance level and have the expected signs. Firm quality measured by abnormal earnings is significant at the 5\% level as shown in columns (2), (4) and (6) but does not carry the expected negative sign. The dynamic panel framework used to model debt maturity is appropriate as lagged debt maturity has a significantly positive coefficient at the $1 \%$ significance level in all six models. This finding is consistent with recent theoretical and empirical research on optimal debt maturity structures (Jun and Jen, 2003; Ozkan, 2000; Antoniou et al., 2006).

The results show that leverage is significantly positive at the $1 \%$ level in columns (2), (4) and (6), weakly significant in columns (1) and (5), and insignificant in column (3). The finding that leverage increases with debt maturity is consistent with the results in the leverage equation and suggests that the positive relation between leverage and maturity is robust to different model estimations. It provides further evidence that high liquidity risk caused by a high-leverage policy can be moderated by long-term debt maturity (Diamond, 1991, 1993) and that long-term (short-term) debt maturity and high (low) leverage can be used as complementary strategies to avoid the threat of suboptimal liquidation. Empirically, this finding is consistent with previous studies estimating a single debt maturity equation (Stohs and Mauer, 1996; Antoniou et al., 2006) as well as studies adopting the simultaneousequations approach (Elyasiani et al., 2002).

The results in columns (1), (2), (5) and (6) reveal that the coefficient on the interaction term between growth opportunities and leverage is insignificant. Hence, the overall effect of debt maturity on leverage is unaffected by the level of growth opportunities. Debt maturity increases with leverage irrespective of the presence of growth prospects and the associated underinvestment problem. The finding does not support the role of short-term debt as a substitute for a low-leverage strategy, and it

\footnotetext{
${ }^{24}$ Diagnostic tests show that all the models use valid instruments and do not have second-order autocorrelation; see the $\mathrm{AR}(2)$ and Sargan tests.
} 
poses an interesting question as to whether UK firms consider debt maturity as a tool to mitigate underinvestment incentives.

As Table 3 shows, the coefficient on growth opportunities is positive and only weakly significant at the $10 \%$ significant level, except in column (1) where it is insignificant. ${ }^{25}$ Taken together with the above finding, this suggests that there is no economic relation between growth opportunities and debt maturity. Firms lower leverage but do not shorten the maturity of their debt in order to moderate the underinvestment problem. This finding is partially consistent with Myers' (1977) prediction that both leverage and debt maturity should be inversely related to growth opportunities. Empirically, it is inconsistent with Barclay et al. (1995), Barclay et al. (2003) and Johnson (2003), who document strong evidence for a negative relation between growth opportunities and debt maturity in the US. The finding is inconsistent with prior UK evidence by Ozkan (2000) but is in line with Antoniou et al. (2006). The results are also in line with Stohs and Mauer (1996) and particularly with Elyasiani et al. (2002), who adopt the simultaneous-equations approach to model leverage and debt maturity.

There are a number of possible reasons why growth opportunities and debt maturity are not related. Using a single-equation approach, Stohs and Mauer (1996) find that in a debt maturity model in which leverage is included as an exogenous regressor, growth opportunities do not have a significantly negative effect on maturity. ${ }^{26}$ They suggest that firms with high growth have low leverage and therefore little incentive to shorten the maturity of their debt to alleviate underinvestment problems. Our results are broadly in line with this argument, though it remains questionable whether lowering leverage alone can completely eliminate underinvestment incentives so that a short-term debt maturity strategy is not required. A reduction in leverage generally leads to the loss of interest tax shields, and so firms will only lower leverage until the benefit of the reduced agency problem can offset the loss of the tax shields. Childs et al.'s (2005) theoretical model of the interaction between corporate financing and investment provides a more plausible explanation for the insignificant relation between growth opportunities and debt maturity. It posits

\footnotetext{
25 This finding is robust to the single-equation framework in which we estimate the debt maturity equation without including leverage as a regressor or assuming that leverage is exogenous.

${ }^{26}$ Note, however, that this single-equation approach may suffer from potential simultaneous-equations bias.
} 
that when firms have little financial flexibility to change their capital structure and debt maturity structure, they will lower leverage but will not shorten the maturity of their debt. While using short-term debt maturity can mitigate the agency cost of underinvestment, it may considerably increase the cost of suboptimal liquidation. To the extent to which the cost of the liquidity risk outweighs the benefit of a reduction in agency costs, it will no longer be beneficial for a firm to shorten the maturity of its debt. ${ }^{27}$ This argument is particularly consistent with our observation that UK firms rely considerably on short-term debt, thus facing potentially high liquidity risk that may constrain them from further shortening the maturity of their debt; see also Table A3 in Appendix 2.

Finally, the finding that there is no economic relation between growth opportunities and debt maturity helps explain the results for the leverage equation. Since firms only use leverage to mitigate underinvestment incentives, the choice of debt maturity does not affect the relation between growth opportunities and leverage. Debt maturity and leverage are complements in moderating suboptimal liquidation but are neither complements nor substitutes in controlling underinvestment problems. The finding demonstrates why the interaction term between growth opportunities and debt maturity is insignificant in the leverage equation and further corroborates the evidence that debt maturity does not exert any attenuation effects on the relation between growth opportunities and leverage.

\section{(iii) Results for the Investment Equation}

Table 4 presents the results for eight models of investment with the baseline specifications reported in the first two columns. The IV estimator is used in columns (1), (3), (5) and (7), and the two-step GMM estimator is used in columns (2), (4), (6) and (8). The control variables enter the investment equation with the expected signs. Lagged investment is statistically significant in all models at the 5\% significance level except in model (6), thus supporting the existence of an accelerator effect in which current investment is partly determined by past investment. The results also show that lagged growth opportunities have a positive impact on the current level of investment at the $1 \%$ significance level except in columns (5) and (6), which is largely consistent

\footnotetext{
${ }^{27}$ Recent dynamic models by Titman and Tsyplakov (2007) and Moyen (2007) quantify the cost of debt overhang and postulate that underinvestment remains a problem with both long-term and shortterm debt and thus cannot be alleviated simply by shortening debt maturity.
} 
with the argument that high-growth firms tend to make more investments. The results for lagged cash flow are mixed, with the coefficient being positive at the $1 \%$ significance level in models (3), (4) and (8) but insignificant in the other models.

The results in columns (1), (2), (5) and (6) show that lagged leverage is negatively related to firm investment at the $1 \%$ significance level. This finding is consistent with previous empirical evidence (Lang et al., 1996; Aivazian et al., 2005a, $2005 \mathrm{~b}$ ) and supports the prediction of agency theory that there is a negative relation between leverage and investment. ${ }^{28}$ As discussed in Section 2, such evidence may support the underinvestment hypothesis for two reasons. When underinvestment incentives are not sufficiently alleviated due to the high costs of leverage adjustments or high growth opportunities are not recognised sufficiently early, the maintenance of high leverage or the insufficient reduction of leverage ex ante will result in underinvestment ex post.

The coefficient on the interaction term between lagged leverage and growth opportunities is insignificant except in model (5), where it is weakly significant at the $10 \%$ significance level. Similar results are also obtained in models (3) and (4), where lagged leverage is not included to eliminate any potential correlation between leverage and its interaction with growth opportunities. With respect to the overall effect of growth opportunities on investment, this finding does not support the hypothesis that adopting an initial low-leverage policy helps magnify the positive relation between growth opportunities and investment. If a low-leverage strategy was an effective vehicle to control underinvestment problem, one would expect the coefficient on the interaction term to be significantly negative. Our results, in contrast, suggest that while high-growth firms actively lower leverage to moderate incentive problems, the reduction in the agency cost of risky debt overhang may be small in magnitude, making them unable to pursue more valuable growth opportunities ex post.

The results in columns (1), (2), (7) and (8) provide no empirical support for an economic relation between debt maturity and firm investment, which is inconsistent with previous evidence (e.g., Aivazian et al., 2005b). However, we find that the coefficient on the interaction term between debt maturity and growth opportunities is

\footnotetext{
${ }^{28}$ Adedeji (1998) analyses a cross-section sample of UK firms in 1996 and finds that leverage does not have a negatively significant effect on investment. Unlike our study, however, the author measures investment by the change in total assets over the period 1993-1996.
} 
negative at the $1 \%$ significance level in models (1)-(4) and (7)-(8). Note that the total effect of growth opportunities on investment is the sum of the stand-alone coefficient on growth opportunities and the coefficient on this interaction term multiplied by debt maturity. This finding, therefore, suggests that long-term debt maturity attenuates the positive relation between lagged growth opportunities and the current level of investment. Taken together with the previous finding from the debt maturity equation, this suggests that while firms do not actively shorten the maturity of their debt to mitigate underinvestment incentives, long-term debt maturity limits firms from exploiting valuable growth opportunities and creates underinvestment ex post.

\section{(iv) Underinvestment and Overinvestment Incentives}

Jensen and Meckling (1976) and Jensen (1986) show that managers in low-growth but cash-generating industries have incentives to invest in risky projects because they only bear partial costs should the project generate a negative NPV. One possible measure to alleviate this overinvestment problem is to increase the level of debt, which pre-commits managers to pay out interest and principal, thereby reducing the free cash flow available that otherwise would be over-invested in new projects (Jensen, 1986; Stulz, 1990). The prediction follows that, for firms with low-growth, more debt should be used to deter overinvestment; i.e., leverage is negatively related to growth opportunities and investment outcomes.

While underinvestment and overinvestment problems have several similar predictions for the potential interactions among leverage, growth opportunities and investment, they have different implications for firms with different growth prospects. The underinvestment problem analysed in the previous sections is more likely to be present in high-growth firms, while the overinvestment problem is more likely to arise in low-growth firms. To test the robustness of the evidence for the underinvestment hypothesis and to examine potential result differences for high-growth versus lowgrowth firms, we re-estimate the system-based model given by Equations (1), (2) and (3) using an additional interaction term between a variable of interest and a highgrowth dummy variable equal to 1 if growth is above median growth and 0 otherwise.

The results in Table 5 for the leverage equation show that for low-growth firms, leverage is positively related to growth opportunities at the $1 \%$ significance level, which is inconsistent with the overinvestment hypothesis. In contrast, the coefficient on leverage interacted with the high-growth dummy is significantly 
negative and has a larger magnitude than the coefficient on growth opportunities, suggesting that the overall effect of growth opportunities on leverage is significantly negative for high-growth firms. This finding corroborates the results in Table 2 in supporting the underinvestment hypothesis.

The results in Table 6 show that the coefficients on growth opportunities and the interaction with the high-growth dummy variable are insignificant across all debt maturity specifications. This finding is consistent with the results reported in Table 3 and indicates that growth opportunities do not exert any significant effects on debt maturity for both low- and high-growth firms.

Next, we include leverage interacted with the high-growth dummy as well as debt maturity interacted with the high-growth dummy in the investment equation. For brevity, we only report the two-step GMM estimates in Table 7. The results reveal that the coefficient on leverage is significantly negative at the $1 \%$ significance level, while the coefficient on leverage interacted with the high-growth dummy is insignificant. This suggests that leverage only has a significant impact on investment in the case of low-growth firms, which is consistent with the overinvestment hypothesis regarding the disciplining role of leverage for firms with limited growth prospects (Jensen, 1986; Stulz, 1990). The interaction term between debt maturity and the high-growth dummy is positive and significant at the $1 \%$ significance level. However, the stand-alone coefficient on debt maturity is insignificant. Hence, we find little empirical support for a significant relation between debt maturity and investment for both low- and high-growth firms.

\section{(v) Operating Leases, Leverage, Debt Maturity and Investment}

Recent accounting research suggests that operating leases represent a significant source of off-balance sheet asset financing and that they should be taken into consideration when evaluating a firm's financing and investment activities (Imhoff et al., 1991; Beattie et al., 1998; Beattie et al., 2000). Following this argument, we assess the robustness of our empirical findings by explicitly accounting for operating leases. ${ }^{29}$ We collect data on lease commitments in each of the next five years and after five years from the Worldscope database and then merge these data with our original panel dataset. Missing values are set to zero under the assumption that the

\footnotetext{
${ }^{29}$ We are grateful to the referee for this suggestion.
} 
corresponding leasing data are immaterial and do not warrant separate disclosure. ${ }^{30}$ The capitalised value of operating leases is then estimated using a widely-used DCF method suggested by Imhoff et al. (1991). ${ }^{31}$

The mean capitalised lease liability is estimated at $£ 18$ million, accounting for nearly $9 \%$ of the mean total debt before capitalisation. Of this estimate, $£ 9.4$ million can be categorised as long-term (i.e., due in more than one year), representing about $6.5 \%$ of pre-capitalisation long-term debt. ${ }^{32}$ Capitalised lease assets amount to $£ 12$ million, representing $1.7 \%$ of total assets before capitalisation. The mean increase in capital expenditures post-capitalisation is $8.6 \%$ (or $£ 3$ million in value). Leverage increases by $2.2 \%$ while debt maturity decreases by $4.4 \%$ after the capitalisation process. Adjusted investment based on net capital expenditures increases by $2 \%$, while growth opportunities marginally decrease by 0.01 . Profitability and cash flow both increase by approximately $2.5 \%$ after capitalisation. Overall, the above results show that the capitalisation of operating leases has a moderate effect on the main variables under consideration in this paper.

We next re-estimate our system-based model given by Equations (1), (2) and (3) using the variables adjusted for capitalised operating leases. The results for the leverage, debt maturity and investment equations are reported in Tables A4, A5 and A6 in Appendix 3, respectively. A general examination of these results suggests that the main empirical findings of the paper still hold well. In the leverage model, growth opportunities have a significantly negative impact on leverage, which is consistent with the underinvestment hypothesis. The coefficient on the interaction term between growth opportunities and debt maturity is insignificant, which is not supportive of the attenuation effect. Leverage and debt maturity exhibit a significantly positive relation in both the leverage and debt maturity equations, which is in line with the liquidity

\footnotetext{
${ }^{30}$ In 2004, Datastream removed its Company Account database and replaced it with the Worldscope database, which provides leasing data in a format consistent with Imhoff et al.'s (1991) approach.

${ }^{31}$ This DCF method has been employed by credit rating agencies since the early 1990s. Beattie et al. (1998) adapt Imhoff et al.'s (1991) capitalisation procedure for a sample of UK firms; see also Beattie et al. (2000) and Goodacre (2001). However, this modified approach requires the data on leases (i.e., leasing footnotes to annual reports) to be collected manually and may be inconsistent with the standardised leasing data available on Worldscope used in this paper.

${ }^{32}$ We follow Imhoff et al. (1991) and assume that the capitalised lease asset represents $70 \%$ of the capitalised lease liability. Shareholders' equity is adjusted to reflect the cumulative profit and loss impact of capitalisation. EBITD is increased by the operating lease rental payments, which are assumed to equal next year's lease commitment (Beattie et al., 1998). Capital expenditures is adjusted by the annual change in the capitalised lease liability; see also Damodaran (2009).
} 
risk hypothesis. In the latter model, there is little evidence that growth opportunities have a significantly negative impact on debt maturity. ${ }^{33}$ In the investment equation, investment is negatively affected by leverage but not by debt maturity; the former finding is consistent with agency theory. In sum, the results after accounting for operating leases are qualitatively similar to our main empirical findings. ${ }^{34}$

\section{(vi) Robustness Tests}

In this section, we conduct several additional robustness tests of our empirical findings by using alternative measures of debt maturity and investment, and considering alternative specifications of the investment model.

In the empirical analysis above, we consider debt maturity as the ratio of longterm debt due in more than one year to total debt. This measure is appropriate given the UK context (see footnote 11) and is generally consistent with measures used in recent research on debt maturity (e.g., Antoniou et al., 2006). Our unreported tests further show that the main empirical findings are insensitive to our choice of the debt maturity measure. We obtain qualitatively similar results when considering debt maturity as the ratio of debt due in more than two years to total debt.

While we follow the majority of research on the interaction between corporate financing and investment (Lang et al., 1996; Aivazian et al., 2005a, 2005b; Firth et al., 2008) and measure investment as net capital expenditures, some recent studies suggest that research and development (R\&D) expenses could also be considered a form of investment (e.g., Kaplan and Zingales, 1997). ${ }^{35}$ To address this, we collect data on $R \& D$ expenses and merge them with our original dataset. We then define investment as the sum of net capital expenditures and $R \& D$, all divided by fixed assets lagged one period. The unreported results regarding the impact of leverage and debt maturity on investment are qualitatively similar. However, unlike the results in Table 4, the interaction term between growth opportunities and debt maturity only has

\footnotetext{
${ }^{33}$ While the Sargan test is rejected in debt maturity models, the $A R(2)$ test is not, suggesting that the error is not serially correlated and the IV and GMM estimates are still consistent.

${ }^{34}$ Yan (2006) suggests that leases and debt may act as strategic substitutes in controlling market imperfections including underinvestment incentives. While this hypothesis warrants further empirical research, our main findings are generally robust to the cases where leases (both capital and 'capitalised' operating) are included in or excluded from debt.

${ }^{35}$ We thank the referee for pointing this out.
} 
a significant and negative effect on investment in two models. ${ }^{36}$ In a related and final robustness test, we consider an alternative specification for the investment model. Specifically, following Whited (1992) and Bond and Meghir (1994), we estimate an Euler equation for investment. The results from this alternative specification are qualitatively similar to those obtained by estimating the Tobin's $q$ model of investment.

\section{CONCLUSIONS}

This paper examines the potential interactions of corporate financing and investment decisions in the presence of incentive problems in order to address two main research questions. First, it investigates how a firm makes a joint choice regarding leverage and debt maturity in order to alleviate the underinvestment problem caused by risky debt overhang. Second, it examines the extent to which this ex ante restructuring of leverage and debt maturity affects the firm's investment outcomes. We develop a system-based framework that models the theoretical links among leverage, debt maturity and investment while controlling for endogeneity and dynamics in these financing and investment decisions. Our results provide a number of fresh insights into the interactions between corporate financing and investment.

Using UK company data over the period 1996-2003, we find that firms with valuable growth opportunities control the underinvestment problem by reducing leverage but not by shortening the maturity of their debt. There is no significant economic relation between debt maturity and growth opportunities; debt maturity does not attenuate the negative effect of growth opportunities on leverage as reported in previous US-based studies such as Johnson (2003) and Billett et al. (2007). Firms prefer a low-leverage strategy to a short-term debt maturity strategy because using too much short-term debt exposes them to the high cost of suboptimal liquidation, which may outweigh the benefits of reduced agency costs (Childs et al., 2005). In the UK context, this argument is particularly relevant as UK firms rely considerably on shortterm debt and are more likely to be constrained from shortening their debt maturity. Overall, the above finding is only partially consistent with the underinvestment

\footnotetext{
${ }^{36}$ Note, however, that R\&D expenses may proxy for future growth prospects (Titman and Wessels, 1988; Johnson, 2003), in which case there may be a potential simultaneity problem in the investment equation as investment including $\mathrm{R} \& \mathrm{D}$ expenses and growth opportunities are interdependent.
} 
hypothesis, which predicts that leverage and maturity are negatively affected by growth opportunities.

The paper also provides strong empirical support for a positive relation between leverage and debt maturity structure, suggesting that these financing instruments can be used as strategic complements in moderating liquidity risk. This finding does not support the argument that leverage and debt maturity are strategic substitutes in controlling underinvestment incentives and thus should exhibit a negative relation. Taken together with the first finding, this paper argues that liquidity risk and financial flexibility considerations play a more important role than underinvestment incentives in determining a firm's joint choice of leverage and maturity.

Furthermore, we find that while UK firms adopt a low-leverage strategy in order to alleviate underinvestment incentives, there is little evidence that this strategy enables them ex post to exploit more valuable investment opportunities. In contrast, the results suggest that leverage exerts a negative effect on investment. One possible explanation for this finding is that lowering leverage does not sufficiently and completely alleviate underinvestment incentives; as a result, outstanding debt curtails investment ex post. This finding is most consistent with the overinvestment hypothesis that posits a disciplining role of leverage for firms with limited growth opportunities. Finally, the results show that while debt maturity does not have any direct impact on investment, having long-term debt maturity appears to discourage firms from exploiting valuable growth opportunities and creates underinvestment ex post. 


\title{
APPENDIX 1
}

\author{
Table A1
}

\section{Variable Definitions}

\begin{tabular}{lllc}
\hline $\begin{array}{l}\text { Panel A: Leverage equation } \\
\text { Leverage is measured by total debt divided by the market value of equity plus book value of debt }\end{array}$ \\
\hline No & \multicolumn{1}{c}{ Control variable } & \multicolumn{1}{c}{ Definition } & $\begin{array}{c}\text { Expected } \\
\text { sign }\end{array}$ \\
\hline 1 & Growth opportunities & $\begin{array}{l}\text { Market value of equity plus book value of debt } \\
\text { divided by total assets }\end{array}$ & - \\
2 & Tangibility & Ratio of fixed assets to total assets & + \\
3 & Profitability & Ratio of EBITD to total assets & $+/-$ \\
4 & Non-debt tax shields & Ratio of depreciation to total assets & - \\
5 & Size & Log of total assets in 1995 price & + \\
\hline
\end{tabular}

Panel B: Debt maturity equation

Debt maturity is measured by long-term debt that matures after one year divided by total debt

\begin{tabular}{|c|c|c|c|}
\hline No & Control variable & Definition & $\begin{array}{l}\text { Expected } \\
\text { sign }\end{array}$ \\
\hline 1 & Growth opportunities & $\begin{array}{l}\text { Market value of equity plus book value of debt } \\
\text { divided by total assets }\end{array}$ & - \\
\hline 2 & Asset maturity structure & $\begin{array}{l}\text { Net property, plant and equipment (PPE) } \\
\text { divided by depreciation }\end{array}$ & + \\
\hline 3 & Size & Log of total assets in 1995 price & + \\
\hline 4 & Volatility & $\begin{array}{l}\text { Difference between annual \% change in EBITD } \\
\text { and average of this change }\end{array}$ & - \\
\hline 5 & $\begin{array}{l}\text { Firm quality (Abnormal } \\
\text { earnings) }\end{array}$ & $\begin{array}{l}\text { First difference of EPS in years } t+1 \text { and } t \text { to } \\
\text { share price in year } t\end{array}$ & - \\
\hline 6 & Term structure & $\begin{array}{l}\text { Difference between ten year government bond } \\
\text { and three-month treasury bills }\end{array}$ & + \\
\hline 7 & Tax & Total tax charge divided by pre-tax income & $+/-$ \\
\hline
\end{tabular}

\section{Panel C: Investment equation}

Investment is measured by capital expenditures less depreciation, all divided by lagged fixed assets

\begin{tabular}{lllc}
\hline No & Control variable & \multicolumn{1}{c}{ Definition } & $\begin{array}{c}\text { Expected } \\
\text { sign }\end{array}$ \\
\hline 1 & Tobin's Q & $\begin{array}{l}\text { Market value of equity plus book value of debt } \\
\text { divided by total assets }\end{array}$ & + \\
& & EBITDA plus depreciation, all divided by total & $+/-$ \\
\hline
\end{tabular}


APPENDIX 2

Table A2

Structure of the Unbalanced Panel Data Set

\begin{tabular}{|c|c|c|}
\hline \multicolumn{3}{|l|}{ Panel A } \\
\hline Year & Number of Observations & $\%$ of the Sample \\
\hline 1996 & 136 & 3.26 \\
\hline 1997 & 561 & 13.45 \\
\hline 1998 & 652 & 15.64 \\
\hline 1999 & 678 & 16.26 \\
\hline 2000 & 678 & 16.26 \\
\hline 2001 & 676 & 16.21 \\
\hline 2002 & 625 & 14.99 \\
\hline 2003 & 164 & 3.93 \\
\hline Total & 4170 & \\
\hline
\end{tabular}

Panel B

\begin{tabular}{ccc}
\hline Number of year observations & Number of Companies & \% of the Sample \\
\hline 5 & 111 & 16.37 \\
6 & 357 & 52.65 \\
7 & 207 & 30.53 \\
8 & 3 & 0.44 \\
\hline Total & $\mathbf{6 7 8}$ & \\
\hline
\end{tabular}

Notes:

We collect an unbalanced panel dataset of UK firms from the Datastream database and impose four restrictions. First, firms operating in financial sectors (i.e., banks, insurance and life assurance companies and investment trusts) and in utilities sectors (i.e., electricity, water and gas distribution) are excluded because they are subject to different regulatory accounting considerations. Second, in order to use the dynamic panel econometric techniques, only firms that have five years or more of observations are retained. Third, observations that have missing data for the variables of interest are removed. The final panel data set consists of 678 firms with 4,170 firm-year observations from 1996 to 2003. 
Table A3

Debt Maturity Structures

\begin{tabular}{lcccccc}
\hline \multicolumn{1}{c}{ Proportion of Debt } & \multicolumn{2}{c}{ All Firms } & \multicolumn{2}{c}{ Small Firms } & \multicolumn{2}{c}{ Large Firms } \\
\hline & Mean & Median & Mean & Median & Mean & Median \\
Due within 1 year & 0.46 & 0.41 & 0.56 & 0.55 & 0.36 & 0.27 \\
Due in more than 1 year & 0.54 & 0.59 & 0.44 & 0.45 & 0.64 & 0.73 \\
- between 1 and 5 years & 0.32 & 0.28 & 0.24 & 0.14 & 0.41 & 0.41 \\
+between 1 and 2 years & 0.09 & 0.03 & 0.09 & 0.03 & 0.10 & 0.03 \\
+between 2 and 5 years & 0.23 & 0.13 & 0.15 & 0.03 & 0.31 & 0.26 \\
Due in more than 2 years & 0.44 & 0.45 & 0.34 & 0.31 & 0.53 & 0.59 \\
Due in more than 5 years & 0.21 & 0.09 & 0.19 & 0.09 & 0.23 & 0.10 \\
\hline
\end{tabular}

Notes:

This table presents an analysis of the proportion of debt with different maturities to total debt. Firms are classified into "small firms" ("large firms") if their size is less (greater) than the median size of the total sample, where size is the natural logarithm of total assets in 1995 price. 


\section{APPENDIX 3}

Table A4

Regression Results for the Leverage Equation with

Operating Lease Capitalisation

\begin{tabular}{|c|c|c|c|c|c|c|c|}
\hline \multicolumn{8}{|c|}{ Dependent variable: Leverage } \\
\hline $\begin{array}{c}\text { Independent } \\
\text { variable }\end{array}$ & $\begin{array}{l}\text { Exp } \\
\text { Sign } \\
\end{array}$ & (1) & (2) & (3) & (4) & (5) & (6) \\
\hline $\operatorname{Leverage}_{(t-1)}$ & + & $\begin{array}{l}0.215 * * \\
(0.086)\end{array}$ & $\begin{array}{l}0.210 * * * \\
(0.069)\end{array}$ & $\begin{array}{l}0.205 * * \\
(0.086)\end{array}$ & $\begin{array}{l}0.204 * * * \\
(0.070)\end{array}$ & $\begin{array}{l}0.243 * * * \\
(0.092)\end{array}$ & $\begin{array}{l}0.233 * * * \\
(0.073)\end{array}$ \\
\hline Maturity $_{(t)}$ & $+/-$ & $\begin{array}{l}0.375 * * * \\
(0.109)\end{array}$ & $\begin{array}{l}0.183 * * * \\
(0.043)\end{array}$ & $\begin{array}{l}0.370 * * * \\
(0.110)\end{array}$ & $\begin{array}{l}0.183 * * * \\
(0.043)\end{array}$ & $\begin{array}{l}0.390 * * \\
(0.111)\end{array}$ & $\begin{array}{l}0.202 * * * \\
(0.043)\end{array}$ \\
\hline${\text { Maturity } \times \text { Growth }_{(t)}}$ & - & $\begin{array}{l}-0.018 * \\
(0.010)\end{array}$ & $\begin{array}{l}-0.013 * \\
(0.008)\end{array}$ & $\begin{array}{l}- \\
-\end{array}$ & $\begin{array}{l}- \\
-\end{array}$ & $\begin{array}{l}-0.029 * \\
(0.016)\end{array}$ & $\begin{array}{l}-0.032 \\
(0.020)\end{array}$ \\
\hline $\operatorname{Growth}_{(t)}$ & - & $\begin{array}{l}-0.014 * * \\
(0.006)\end{array}$ & $\begin{array}{l}-0.019 * * * \\
(0.005)\end{array}$ & $\begin{array}{l}-0.020 * * * \\
(0.005)\end{array}$ & $\begin{array}{l}-0.023^{* * *} \\
(0.004)\end{array}$ & - & - \\
\hline Tangibility $_{(t)}$ & + & $\begin{array}{l}0.131 \\
(0.095)\end{array}$ & $\begin{array}{l}0.225^{* * *} \\
(0.060)\end{array}$ & $\begin{array}{l}0.129 \\
(0.095)\end{array}$ & $\begin{array}{l}0.220 * * * \\
(0.060)\end{array}$ & $\begin{array}{l}0.100 \\
(0.099)\end{array}$ & $\begin{array}{l}0.202 * * * \\
(0.063)\end{array}$ \\
\hline Non-debt tax shields $_{(t)}$ & - & $\begin{array}{l}0.267 \\
(0.343)\end{array}$ & $\begin{array}{l}-0.076 \\
(0.238)\end{array}$ & $\begin{array}{l}0.183 \\
(0.328)\end{array}$ & $\begin{array}{l}-0.132 \\
(0.232)\end{array}$ & $\begin{array}{l}0.315 \\
(0.361)\end{array}$ & $\begin{array}{l}0.005 \\
(0.271)\end{array}$ \\
\hline $\operatorname{Profitability}_{(t)}$ & $+/-$ & $\begin{array}{l}-0.046 \\
(0.033)\end{array}$ & $\begin{array}{l}-0.091 * * * \\
(0.021)\end{array}$ & $\begin{array}{l}-0.045 \\
(0.033)\end{array}$ & $\begin{array}{l}-0.090 * * * \\
(0.020)\end{array}$ & $\begin{array}{l}-0.049 \\
(0.036)\end{array}$ & $\begin{array}{l}-0.090 * * * \\
(0.025)\end{array}$ \\
\hline $\operatorname{Size}_{(t)}$ & + & $\begin{array}{l}-0.023 \\
(0.026) \\
\end{array}$ & $\begin{array}{l}0.008 \\
(0.014) \\
\end{array}$ & $\begin{array}{l}-0.023 \\
(0.026) \\
\end{array}$ & $\begin{array}{l}0.007 \\
(0.014) \\
\end{array}$ & $\begin{array}{l}-0.013 \\
(0.030) \\
\end{array}$ & $\begin{array}{l}0.020 \\
(0.017) \\
\end{array}$ \\
\hline Estimators & & $I V$ & $G M M$ & $I V$ & $G M M$ & $I V$ & $G M M$ \\
\hline First differences & & Yes & Yes & Yes & Yes & Yes & Yes \\
\hline Number of observations & & 2814 & 2814 & 2814 & 2814 & 2814 & 2814 \\
\hline AR(1) test & & $-4.33 * * *$ & $-5.38 * * *$ & $-4.33 * * *$ & $-5.32 * * *$ & $-4.51 * * *$ & $-5.10 * * *$ \\
\hline $\mathbf{A R}(2)$ test & & -0.03 & -0.42 & -0.07 & -0.53 & -0.08 & -0.29 \\
\hline Sargan test & & $4.14(6)$ & $33.83(26)$ & $4.96(6)$ & $34.07(26)$ & $4.51(6)$ & $34.57(26)$ \\
\hline
\end{tabular}

Notes:

This table reports the estimation results from the regression of leverage on lagged leverage, debt maturity, growth opportunities, debt maturity interacted with growth opportunities and the control variables based on Equation (1). All variables are adjusted to account for off-balance-sheet operating leases. See Table A1 for variable definitions. The results are estimated using a two-stage procedure; the results in the first stage used to generate the estimated values of maturity or leverage are not reported. Columns (1), (3) and (5) adopt the IV estimation method, using the second-lagged leverage as an instrument for the first-lagged leverage. Columns (2), (4) and (6) adopt the two-step GMM estimation method, using from the third-lagged leverage to sixth-lagged leverage as instruments for the firstlagged leverage. The instruments for debt maturity include asset maturity and term structure. Lagged control variables are also included as instruments to yield better fit. Year dummies are not included in any models. Standard errors of coefficients are reported in parenthesis. *, ** and *** indicate the coefficient significant at $10 \%, 5 \%$ and $1 \%$ levels, respectively. See Table 2 for notes on test statistics. 
Table A5

Regression Results for the Debt Maturity Equation with

Operating Lease Capitalisation

\begin{tabular}{|c|c|c|c|c|c|c|c|}
\hline \multicolumn{8}{|c|}{ Dependent variable: Debt maturity } \\
\hline $\begin{array}{c}\text { Independent } \\
\text { variable }\end{array}$ & $\begin{array}{l}\text { Exp } \\
\text { Sign }\end{array}$ & (1) & (2) & (3) & (4) & (5) & (6) \\
\hline $\operatorname{Maturity}_{(t-1)}$ & + & $\begin{array}{l}0.006 \\
(0.006)\end{array}$ & $\begin{array}{l}0.009 * * * \\
(0.003)\end{array}$ & $\begin{array}{l}0.006 \\
(0.007)\end{array}$ & $\begin{array}{l}0.010^{* * *} \\
(0.004)\end{array}$ & $\begin{array}{l}0.006 \\
(0.007)\end{array}$ & $\begin{array}{l}0.009 * * * \\
(0.003)\end{array}$ \\
\hline Leverage $_{(t)}$ & $+/-$ & $\begin{array}{l}0.575^{* *} \\
(0.245)\end{array}$ & $\begin{array}{l}0.702 * * * \\
(0.159)\end{array}$ & $\begin{array}{l}0.714 * * \\
(0.360)\end{array}$ & $\begin{array}{l}0.860 * * * \\
(0.200)\end{array}$ & $\begin{array}{l}0.809 * * * \\
(0.229)\end{array}$ & $\begin{array}{l}0.855 * * * \\
(0.135)\end{array}$ \\
\hline Leverage $\times$ Growth $_{(t)}$ & - & $\begin{array}{l}0.281 * * * \\
(0.086)\end{array}$ & $\begin{array}{l}0.349 * * * \\
(0.085)\end{array}$ & $\begin{array}{l}- \\
-\end{array}$ & - & $\begin{array}{l}0.212 * * * \\
(0.076)\end{array}$ & $\begin{array}{l}0.291 * * * \\
(0.079)\end{array}$ \\
\hline $\operatorname{Growth}_{(t)}$ & - & $\begin{array}{l}-0.039 * * * \\
(0.015)\end{array}$ & $\begin{array}{l}-0.025 \\
(0.016)\end{array}$ & $\begin{array}{l}-0.005 \\
(0.016)\end{array}$ & $\begin{array}{l}0.005 \\
(0.014)\end{array}$ & - & - \\
\hline $\operatorname{Size}_{(t)}$ & + & $\begin{array}{l}0.160^{* * * *} \\
(0.027)\end{array}$ & $\begin{array}{l}0.171 * * * \\
(0.033)\end{array}$ & $\begin{array}{l}0.129 * * * \\
(0.031)\end{array}$ & $\begin{array}{l}0.129 * * * \\
(0.036)\end{array}$ & $\begin{array}{l}0.171^{* * * *} \\
(0.031)\end{array}$ & $\begin{array}{l}0.171 * * * \\
(0.037)\end{array}$ \\
\hline Maturity of assets $(t)$ & + & $\begin{array}{l}0.006 \\
(0.008)\end{array}$ & $\begin{array}{l}-0.000 \\
(0.009)\end{array}$ & $\begin{array}{l}0.003 \\
(0.009)\end{array}$ & $\begin{array}{l}0.000 \\
(0.009)\end{array}$ & $\begin{array}{l}0.003 \\
(0.008)\end{array}$ & $\begin{array}{l}-0.000 \\
(0.009)\end{array}$ \\
\hline $\operatorname{Tax~ratio}_{(t)}$ & $+/-$ & $\begin{array}{l}-0.002 \\
(0.003)\end{array}$ & $\begin{array}{l}0.001 \\
(0.002)\end{array}$ & $\begin{array}{l}-0.001 \\
(0.003)\end{array}$ & $\begin{array}{l}0.001 \\
(0.002)\end{array}$ & $\begin{array}{l}-0.001 \\
(0.003)\end{array}$ & $\begin{array}{l}0.002 \\
(0.002)\end{array}$ \\
\hline 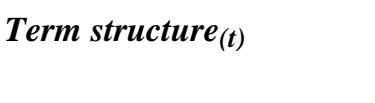 & + & $\begin{array}{l}-0.014 * * \\
(0.007)\end{array}$ & $\begin{array}{l}-0.007 \\
(0.007)\end{array}$ & $\begin{array}{l}-0.014 * \\
(0.007)\end{array}$ & $\begin{array}{l}-0.006 \\
(0.008)\end{array}$ & $\begin{array}{l}-0.013 * \\
(0.007)\end{array}$ & $\begin{array}{l}-0.006 \\
(0.007)\end{array}$ \\
\hline $\operatorname{Volatility}_{(t)}$ & & $\begin{array}{l}-0.003 * \\
(0.002)\end{array}$ & $\begin{array}{l}-0.001 \\
(0.002)\end{array}$ & $\begin{array}{l}-0.003 \\
(0.002)\end{array}$ & $\begin{array}{l}-0.001 \\
(0.002)\end{array}$ & $\begin{array}{l}-0.003 * \\
(0.002)\end{array}$ & $\begin{array}{l}-0.000 \\
(0.002)\end{array}$ \\
\hline Quality $_{(t)}$ & - & $\begin{array}{l}0.051 \\
(0.089) \\
\end{array}$ & $\begin{array}{l}0.134 \\
(0.092) \\
\end{array}$ & $\begin{array}{l}0.095 \\
(0.105) \\
\end{array}$ & $\begin{array}{l}0.180 * \\
(0.099) \\
\end{array}$ & $\begin{array}{l}0.096 \\
(0.092) \\
\end{array}$ & $\begin{array}{l}0.169^{*} \\
(0.090) \\
\end{array}$ \\
\hline Estimators & & $I V$ & GMM & $I V$ & GMM & $I V$ & GMM \\
\hline First differences & & Yes & Yes & Yes & Yes & Yes & Yes \\
\hline Number of observations & & 2762 & 2762 & 2762 & 2762 & 2762 & 2762 \\
\hline$\overline{A R(1)}$ test & & $-4.21 * * *$ & $-4.14 * * *$ & $-4.22 * * *$ & $-4.16 * * *$ & $-4.14 * * *$ & $-4.10 * * *$ \\
\hline $\operatorname{AR}(2)$ test & & -0.05 & 0.27 & -0.06 & 0.19 & 0.13 & 0.38 \\
\hline Sargan test & & $\begin{array}{l}15.38(2) \\
* * *\end{array}$ & $\begin{array}{l}100.31(19) \\
* * *\end{array}$ & $\begin{array}{l}24.61(2) \\
* * *\end{array}$ & $\begin{array}{l}106.92(19) \\
* * *\end{array}$ & $\begin{array}{l}19.73(2) \\
* * *\end{array}$ & $\begin{array}{l}95.29(19) \\
* * *\end{array}$ \\
\hline
\end{tabular}

Notes:

This table reports the estimation results from the regression of debt maturity on lagged debt maturity, leverage, growth opportunities, leverage interacted with growth opportunities and the control variables based on Equation (2). All variables are adjusted to account for off-balance-sheet operating leases. See Table A1 for variable definitions. Columns (1), (3) and (5) adopt the IV estimation method, using the second-lagged maturity as an instrument for the first-lagged maturity. Columns (2), (4) and (6) adopt the two-step GMM estimation method, using from the third-lagged maturity to fifth-lagged maturity as instruments for the first-lagged maturity. The instruments for leverage include non-debt tax shields, tangibility and profitability, all in levels. Year dummies are not included in any models. Standard errors of coefficients are reported in parenthesis. $* * *$ and $* * *$ indicate the coefficient significant at $10 \%, 5 \%$ and $1 \%$ levels, respectively. See Table 2 for notes on test statistics. 
Table A6

Regression Results for the Investment Equation with Operating Lease Capitalisation

\begin{tabular}{|c|c|c|c|c|c|c|c|c|c|}
\hline \multicolumn{10}{|c|}{ Dependent variable: Investment } \\
\hline Independent variable & Exp sign & (1) & (2) & (3) & (4) & (5) & (6) & (7) & (8) \\
\hline \multirow[t]{2}{*}{ Investment $_{(t-1)}$} & + & $0.122 *$ & 0.083 & $0.187 * * *$ & 0.164 & 0.091 & 0.076 & $0.190 * * *$ & $0.183 * * *$ \\
\hline & & $(0.064)$ & $(0.055)$ & $(0.058)$ & $(0.048)$ & $(0.063)$ & $(0.061)$ & $(0.054)$ & $(0.050)$ \\
\hline \multirow[t]{2}{*}{ Leverage $_{(t-1)}$} & - & $-1.371 * *$ & $-1.321 * * *$ & - & - & $-4.451 * * *$ & $-2.722 * * *$ & - & - \\
\hline & & $(0.583)$ & $(0.498)$ & - & - & $(1.393)$ & $(1.004)$ & - & - \\
\hline \multirow{2}{*}{ Leverage $\times$ Growth $_{(t-1)}$} & - & $-0.259 *$ & -0.210 & -0.212 & -0.249 & $-0.681 * *$ & $-0.489 *$ & - & - \\
\hline & & $(0.135)$ & $(0.154)$ & $(0.201)$ & $(0.174)$ & $(0.338)$ & $(0.292)$ & - & - \\
\hline \multirow[t]{2}{*}{ Maturity $(t-1)$} & - & -0.400 & -0.342 & - & - & - & - & $-0.676^{* *}$ & $-0.431 *$ \\
\hline & & $(0.321)$ & $(0.252)$ & - & - & - & - & $(0.334)$ & $(0.250)$ \\
\hline \multirow[t]{2}{*}{${\text { Maturity } \times \text { Growth }_{(t-1)}}$} & - & 0.003 & 0.001 & 0.009 & 0.014 & - & - & 0.007 & 0.014 \\
\hline & & $(0.010)$ & $(0.010)$ & $(0.014)$ & $(0.012)$ & - & - & $(0.010)$ & $(0.010)$ \\
\hline \multirow[t]{2}{*}{$\operatorname{Growth}_{(t-1)}$} & + & $0.046 * *$ & 0.041 & $0.064 * *$ & $0.070 * *$ & $0.052 *$ & 0.047 & 0.025 & $0.041 * * *$ \\
\hline & & $(0.021)$ & $(0.028)$ & (0.029) & $(0.029)$ & $(0.031)$ & $(0.032)$ & $(0.017)$ & $(0.016)$ \\
\hline $\operatorname{Cash}_{\operatorname{flow}}^{(t-1)}$ & + & 0.007 & 0.048 & $0.542 * * *$ & 0.553 & -0.603 & -0.126 & 0.396 & $0.593 * * *$ \\
\hline \multirow{3}{*}{$\begin{array}{l}\text { Estimators } \\
\text { First differences } \\
\text { Number of } \\
\text { observations }\end{array}$} & & $I V$ & $G M M$ & $I V$ & $G M M$ & $I V$ & $G M M$ & $I V$ & $G M M$ \\
\hline & & Yes & Yes & Yes & Yes & Yes & Yes & Yes & Yes \\
\hline & & 1456 & 1456 & 2136 & 2136 & 2136 & 2136 & 2136 & 2136 \\
\hline \multicolumn{2}{|l|}{ AR(1) test } & $-3.79 * * *$ & $-3.55 * * *$ & $-3.44 * * *$ & $-3.14 * * *$ & $-3.60 * * *$ & $-3.21 * * *$ & $-3.19 * * *$ & $-3.02 * * *$ \\
\hline \multirow{2}{*}{\multicolumn{2}{|c|}{$\begin{array}{l}\text { AR(2) test } \\
\text { Sargan test }\end{array}$}} & -0.38 & -0.55 & 0.99 & 0.52 & -0.73 & -0.44 & 0.48 & 0.58 \\
\hline & & $14.22(14)$ & $31.37(27)$ & - & $17.69(14)$ & $2.68(3)$ & $22.18(17)$ & $5.17(3)$ & $23.70(17)$ \\
\hline
\end{tabular}

Notes: This table reports the results for the regression of investment on leverage, debt maturity, their interaction terms with growth opportunities, and the control variables, based on Equation (3). All variables are adjusted to account for off-balance-sheet operating leases. See Table A1 for variable definitions, Table 2 for notes on test statistics and instruments for debt maturity and leverage. Columns (1), (3), (5) and (7) adopt the IV estimation method, using the second-lagged investment as the instrumental variable for the first-lagged investment. Columns (2), (4), (6) and (8) adopt the two-step GMM estimation method, using from the third-lagged investment to fifth-lagged investment as instruments for the first-lagged investment. Year dummies are not included in any models. Standard errors of coefficients are reported in parenthesis. $*, * *$ and $* * *$ indicate the coefficient significant at $10 \%, 5 \%$ and $1 \%$ levels, respectively. 


\section{REFERENCES}

Adedeji, A. (1998), 'Does the Pecking Order Hypothesis Explain the Dividend Payout Ratios of Firms in the UK', Journal of Business Finance and Accounting, Vol. 25, pp. 1127-55.

Aivazian, V.A., Y. Ge, and J. Qiu (2005a), 'The Impact of Leverage on Firm Investment: Canadian Evidence', Journal of Corporate Finance, Vol. 11, pp. 277-91.

(2005b), 'Debt Maturity Structure and Firm Investment', Financial Management, Vol. 34, pp. 107-19.

Anderson, T.W. and C. Hsiao (1982), 'Formulation and Estimation of Dynamic Models Using Panel Data', Journal of Econometrics, Vol. 18, pp. 47-82.

Ann, S., D.J., Denis, and D.K., Denis (2006), 'Leverage and Investment in Diversified Firms', Journal of Financial Economics, Vol. 79, pp. 317-37.

Antoniou, A., Y. Guney, and K. Paudyal (2006), 'The Determinants of Corporate Debt Maturity Structure: Evidence from France, Germany and the UK', European Financial Management, Vol. 12, pp. 161-94.

(2008), 'The Determinants of Capital Structure: Capital Market-

Oriented versus Bank-Oriented Institutions', Journal of Financial and Quantitative Analysis, Vol. 43, pp. 59-92.

Arellano, M. and S.R. Bond (1991), 'Some Tests of Specification for Panel Data: Monte Carlo Evidence and an Application to Employment Equations', Review of Economic Studies, Vol. 58, pp. 227-97.

Barclay, M.J. and C.W. Smith Jr. (1995), 'The Maturity Structure of Corporate Debt', Journal of Finance, Vol. 50, pp. 609-31.

Barclay, M.J., L.M. Marx, and C.W. Smith Jr. (2003), 'The Joint Determination of Leverage and Maturity', Journal of Corporate Finance, Vol. 9, pp. 149-67.

Beattie, V., K. Edwards, and A. Goodacre (1998), 'The Impact of Constructive Operating Lease Capitalisation on Key Accounting Ratios', Accounting and Business Research, Vol. 28, pp. 233-254.

------ A. Goodacre, and S. Thomson (2000), 'Operating Leases and the Assessment of Lease-Debt Substitutability', Journal of Banking and Finance, Vol. 24, pp. 427-70. 
Billett M.T., TH.D. King, and D.C. Mauer (2007), 'Growth Opportunities and the Choice of Leverage, Debt Maturity, and Covenants', Journal of Finance, Vol. 62, pp. 697-730.

Blundell, R.W. and S.R. Bond (1998), 'Initial Conditions and Moment Restrictions in Dynamic Panel Data Models', Journal of Econometrics, Vol. 87, pp. 115-43.

Bond, S. and C. Meghir (1994), 'Dynamic Investment Models and The Firm's Financial Policy', Review of Economic Studies, Vol. 61, pp. 197-222.

----- J. Elston, J. Mairesse, and B. Mulkay (2003), 'Financial Factors and Investment in Belgium, France, Germany, and the United Kingdom: A Comparison Using Company Panel Data', Review of Economics and Statistics, Vol. 85, pp. 214366.

Brick, I.E. and S.A. Ravid (1985), 'On the Relevance of Debt Maturity Structure', Journal of Finance, Vol. 40, pp. 1423-37.

Childs, P.D., D.C. Mauer, and S.H. Ott (2005), 'Interactions of Corporate Financing and Investment Decisions: The Effects of Agency Conflicts', Journal of Financial Economics, Vol. 76, pp. 667-90.

Cleary, W.S. (1999), 'The Relationship between Firm Investment and Financial Status', Journal of Finance, Vol. 54, pp. 673-92.

----- (2006), 'International Corporate Investment and the Relationship between Financial Constraint Measures', Journal of Banking and Finance, Vol. 30, pp. 1159-80.

----- P. Povel, and M. Raith (2007), 'The U-shaped Investment Curve: Theory and Evidence', Journal of Financial and Quantitative Analysis, Vol. 42, pp. 1-40.

Damodaran, S. (2009), 'Leases, Debt and Value', Journal of Applied Research in Accounting and Finance, Vol. 4, pp. 3-29.

Datta, S., M. Iskandar-Datta, and K. Raman (2005), 'Managerial Stock Ownership and the Maturity Structure of Corporate Debt', Journal of Finance, Vol. 60, 2333-50.

DeAngelo, H. and R. Masulis (1980). 'Optimal Capital Structure under Corporate and Personal Taxation', Journal of Financial Economics, Vol. 8, pp. 3-29.

Dessi, R. and D. Robertson (2003), 'Debt, Incentives and Performance: Evidence from UK Panel Data', Economic Journal, Vol. 113, pp. 903-19.

Diamond, D.W. (1991), 'Debt Maturity Structure and Liquidity Risk', Quarterly Journal of Economics, Vol. 106, pp. 709-37. 
------ (1993), 'Seniority and Maturity of Debt Contracts', Journal of Financial Economics, Vol. 33, pp. 341-68.

Elyasiani, E., Guo, L., and L. Tang (2002), 'The Determinants of Debt Maturity at Issuance: A System-Based Model', Review of Quantitative Finance and Accounting, Vol. 19, pp. 351-77.

Erickson, T. and T.M. Whited (2000), 'Measurement Error and the Relationship between Investment and q', Journal of Political Economy, Vol. 108, pp. 102757.

Fazzari, S., R.G. Hubbard, and B. Petersen (1988), 'Financial Constraints and Corporate Investment', Brookings Papers on Economic Activity, Vol. 1, pp. 144-95.

(2000), 'Investment-Cash Flow Sensitivities Are Useful: A Comment on Kaplan and Zingales', Quarterly Journal of Economics, Vol. 115, pp. 695705.

Firth, M., C. Lin, and S.M.L. Wong (2008), 'Leverage and Investment under a Stateowned Bank Lending Environment: Evidence from China', Journal of Corporate Finance, Vol. 14, pp. 642-53

Flannery, M.J. (1986), 'Asymmetric Information and Risky Debt Maturity Choice', Journal of Finance, Vol. 41, pp. 19-37.

Frank, M.Z., V.K. Goyal, (2007a), 'Trade-off and Pecking Order Theories of Debt', in Eckbo, B.E. (ed). Handbook of Corporate Finance: Empirical Corporate Finance. North Holland, Handbooks of Finance, Elsevier Science.

(2009), 'Capital Structure Decisions: Which Factors are Reliably Important', Financial Management, Vol. 38, pp. 1-37.

Goergen, M. and L. Renneboog (2001), 'Investment Policy, Internal Financing and Ownership Concentration in the UK', Journal of Corporate Finance, Vol. 7, pp. 257-84.

Goodacre, A. (2001), 'The Potential Impact of Enforced Lease Capitalisation in the UK Retail Sector', Discussion Paper No. 01/01, University of Stirling.

Guariglia, A. (2008), 'Internal Financial Constraints, External Financial Constraints and Investment Choice: Evidence from a Panel of UK Firms', Journal of Banking and Finance, Vol. 32, pp. 1795-1809

Harris, M., and A. Raviv (1991), 'The Theory of Capital Structure', Journal of Finance, Vol. 46, 297-356. 
Hart, O., and J. Moore (1994), 'A Theory of Debt Based on the Inalienability of Human Capital', Quarterly Journal of Economics, Vol. 109, pp. 841-79.

Hayashin, F. (1982), 'Tobin's Average Q and Marginal Q: A Neoclassical Interpretation', Econometrica, Vol. 50, pp. 213-24.

Hennessy, C.A. (2004), 'Tobin's Q, Debt Overhang, and Investment', Journal of Finance, Vol. 59, pp. 1717-42.

Homaifar, G., J. Zietz and O. Benkato (1994), 'An Empirical Model of Capital Structure: Some New Evidence', Journal of Business Finance and Accounting, Vol. 21, pp. 1-14.

Hovakimian, G. (2009), 'Determinants of Investment Cash Flow Sensitivity', Financial Management, Vol. 38, pp. 161-83.

Imhoff, E.A., R.C. Lipe, D.W. Wright (1991), 'Operating Leases: Impact of Constructive Capitalization', Accounting Horizons, Vol. 5, pp. 51-63.

Jensen, M. and W. Meckling (1976), 'Theory of the Firm: Managerial Behavior, Agency Costs and Ownership Structure', Journal of Financial Economics, Vol. 3, pp. 305-60.

(1986), 'Agency Costs of Free Cash Flow, Corporate Finance and Takeovers', American Economic Review, Vol. 76, pp. 323-39.

Johnson, S.A. (2003), 'Debt Maturity and the Effects of Growth Opportunities and Liquidity Risk on Leverage', Review of Financial Studies, Vol. 16, pp. 20936.

Jun, S.G. and F.C. Jen (2003), 'Trade-off Model of Debt Maturity Structure', Review of Quantitative Finance and Accounting, Vol. 20, pp. 5-34.

Kane, A., A.J. Marcus, and R.L. McDonald (1985), 'Debt Policy and the Rate of Return Premium to Leverage', Journal of Financial and Quantitative Analysis, Vol. 20, pp. 479-99.

Kaplan, S. and L. Zingales (1997), 'Do Investment-Cash flow Sensitivities Provide Useful Measures of Financing Constraints?', Quarterly Journal of Economics, Vol. 111, pp. 169-215.

(2000), 'Investment-Cash Flow Sensitivities Are Not Valid Measures of Financial Constraints', Quarterly Journal of Economics, Vol. 115, pp. 707-12. Lang, L.E., E. Ofek, and R. Stulz (1996), 'Leverage, Investment and Firm Growth', Journal of Financial Economics, Vol. 40, pp. 3-29. 
Leary, M.T. and M.R. Roberts (2005), 'Do Firms Rebalance Their Capital Structures', Journal of Finance, Vol. 60, pp. 2575-2619.

Lewis, C.M. (1990), 'A Multiperiod Theory of Corporate Financial Policy Under Taxation, Journal of Financial and Quantitative Analysis, Vol. 25, pp. 25-43.

Marchica, M.T. (2007), 'On the Relevance of Ownership Structure in Determining the Maturity of Debt', Working Paper (Manchester Business School).

McConnell, J.J and H. Servaes (1995), 'Equity Ownership and The Two Faces of Debt', Journal of Financial Economics, Vol. 39, pp. 137-51.

Modigliani, F. and H.H. Miller (1958), 'The Cost of Capital, Corporate Finance and the Theory of Investment', American Economic Review, Vol. 49, pp. 261-97. (1963), 'Taxes and the Cost of Capital: A Correction', American Economic Review, Vol. 53, pp. 433-43.

Moyen, N. (2007), 'How Big is the Debt Overhang Problem', Journal of Economic Dynamics and Control, Vol. 31, 433-72.

Myers, S.C. (1977), 'Determinants of Corporate Borrowing', Journal of Financial Economics, Vol. 5, pp. 145-75.

(1984), ‘The Capital Structure Puzzle', Journal of Finance, Vol. 34, pp. 575-92. and N.S. Majluf (1984), 'Corporate Financing and Investments Decisions When Firms Have Information That Investors Do Not Have', Journal of Financial Economics, Vol. 13, pp. 187-221.

Ozkan, A. (2000), 'An Empirical Study of Corporate Debt Maturity Structure', European Financial Management, Vol. 6, pp. 197-212.

----- (2001), 'Determinants of Capital Structure and Adjustment to Long Run Target:

Evidence from UK Company Panel Data', Journal of Business Finance and Accounting, Vol. 28, pp. 175-98.

Rajan, R.G. and L. Zingales (1995), 'What Do We Know about Capital Structure? Some Evidence from International Data', Journal of Finance, Vol. 50, pp. $1421-61$

Smith, C.W. Jr. and J.B. Warner (1979), 'On Financial Contracting: An Analysis of Bond Covenants', Journal of Financial Economics, Vol. 7, pp. 117-61.

Sharpe, S.A. (1991), 'Credit Rationing, Concessionary Lending, and Debt Maturity', Journal of Banking and Finance, Vol. 15, pp. 581-604.

Stulz R.M. (1990), 'Managerial Discretion and Optimal Financing Policies', Journal of Financial Economics, Vol. 26, pp. 3-27. 
Stohs, M.H. and D.C. Mauer (1996), 'The Determinants of Corporate Debt Maturity Structure', Journal of Business, Vol. 69, pp. 279-312.

Titman, S. and R. Wessels (1988), 'The Determinants of Capital Structure Choice', Journal of Finance, Vol. 43, pp. 1-19.

------ and S. Tsyplakov (2007), 'A Dynamic Model of Optimal Capital Structure', Review of Finance, Vol. 11, pp. 401-51.

Whited, T. (1992), 'Debt Liquidity Constraints, and Corporate Investment: Evidence from Panel Data', Journal of Finance, Vol. 47, 1425-60.

Windmeijer, F. (2005), 'A Finite Sample Correction for the Variance of Linear Efficient Two-step GMM Estimators', Journal of Econometrics, Vol. 126, pp. $25-51$.

Wooldridge, J. (2002), Econometric Analysis of Cross Section and Panel Data, $2^{\text {nd }}$ Edition, MIT Press.

Yan, A. (2006), 'Leasing and Debt Financing: Substitutes or Complements', Journal of Financial and Quantitative Analysis, Vol. 41, pp. 709-31. 
Table 1

Summary Statistics of Variables

\begin{tabular}{lrccrc}
\hline \multicolumn{1}{c}{ Variable } & Mean & Std. Dev. & Minimum & Median & Maximum \\
\hline Leverage & 0.228 & 0.189 & 0.000 & 0.189 & 0.886 \\
Debt maturity & 0.538 & 0.325 & 0.000 & 0.587 & 1.000 \\
Investment & 0.082 & 0.459 & -2.000 & 0.020 & 10.000 \\
Tangibility & 0.337 & 0.241 & 0.005 & 0.290 & 0.997 \\
Non-debt tax shields & 0.041 & 0.030 & 0.000 & 0.035 & 0.318 \\
Growth opportunities & 1.794 & 1.470 & 0.500 & 1.324 & 9.800 \\
Profitability & 0.078 & 0.228 & -2.175 & 0.117 & 1.095 \\
Size & 11.513 & 1.974 & 6.838 & 11.330 & 16.809 \\
Asset maturity structure & 3.525 & 2.044 & 0.000 & 3.186 & 10.000 \\
Earnings volatility (\%) & 0.195 & 5.894 & -30.000 & -0.054 & 50.000 \\
Firm quality & 0.006 & 0.070 & -0.369 & 0.000 & 1.244 \\
Term structure (\%) & -0.170 & 1.029 & -2.674 & -0.147 & 2.361 \\
Tax ratio & 0.217 & 0.380 & -1.520 & 0.222 & 2.337 \\
Cash flow & 0.127 & 0.238 & -3.716 & 0.155 & 1.250 \\
\hline
\end{tabular}

Notes:

Leverage is measured by total debt divided by the market value of equity plus book value of debt. Debt maturity is measured by long-term debt that matures after one year divided by total debt. Investment is measured by capital expenditures less depreciation divided by lagged fixed assets. Tangibility is the ratio of fixed assets to total assets. Non-debt tax shields are the ratio of depreciation to total assets. Growth opportunities are measured by the market value of equity plus book value of debt divided by total assets. Profitability is the ratio of EBITD to total assets. Size is the log of total assets in 1995 price. Asset maturity structure is measured by net property, plant and equipment (PPE) divided by depreciation. Earnings volatility is the difference between the annual \% change in EBITD and the average of this change. Firm quality is measured by the first difference of EPS in years $t+1$ and $t$ to share price in year $t$. Term structure is the difference between ten year government bond and threemonth treasury bills. Tax ratio is total tax charge divided by pre-tax income. Cash flow is measured by EBITDA plus depreciation, all divided by total assets. We collected UK company data from the Datastream database. The final panel dataset consists of 678 firms with 4170 firm-year observations from 1996 to 2003. To avoid the effect of outliers, we follow previous research (Cleary, 1999; Aivazian et al., 2005a; 2005b) and winsorise the observations at the 1st and 99th percentiles. 
Table 2

Regression Results for the Leverage Equation

\begin{tabular}{|c|c|c|c|c|c|c|c|}
\hline \multicolumn{8}{|c|}{ Dependent variable: Leverage } \\
\hline $\begin{array}{c}\text { Independent } \\
\text { variable }\end{array}$ & $\begin{array}{l}\text { Exp } \\
\text { Sign }\end{array}$ & (1) & (2) & (3) & (4) & (5) & (6) \\
\hline Leverage $_{(t-1)}$ & + & $\begin{array}{l}0.215 * * * \\
(0.099)\end{array}$ & $\begin{array}{l}0.255^{* * *} \\
(0.076)\end{array}$ & $\begin{array}{l}0.213 * * \\
(0.101)\end{array}$ & $\begin{array}{l}0.254 * * * \\
(0.076)\end{array}$ & $\begin{array}{l}0.233 * * \\
(0.096)\end{array}$ & $\begin{array}{l}0.264 * * * \\
(0.076)\end{array}$ \\
\hline Maturity $_{(t)}$ & $+/-$ & $\begin{array}{l}0.562 * * \\
(0.294)\end{array}$ & $\begin{array}{l}0.353 * * \\
(0.149)\end{array}$ & $\begin{array}{l}0.570 * * \\
(0.300)\end{array}$ & $\begin{array}{l}0.356 * * \\
(0.150)\end{array}$ & $\begin{array}{l}0.485^{*} \\
(0.294)\end{array}$ & $\begin{array}{l}0.329 * * \\
(0.149)\end{array}$ \\
\hline${\text { Maturity } \times \text { Growth }_{(t)}}_{(t)}$ & - & $\begin{array}{l}-0.012 \\
(0.014)\end{array}$ & $\begin{array}{l}-0.013 \\
(0.012)\end{array}$ & $\begin{array}{l}- \\
-\end{array}$ & - & $\begin{array}{l}-0.043 * * * \\
(0.007)\end{array}$ & $\begin{array}{l}-0.040 * * * \\
(0.006)\end{array}$ \\
\hline $\operatorname{Growth}_{(t)}$ & - & $\begin{array}{l}-0.021 * * \\
(0.009)\end{array}$ & $\begin{array}{l}-0.018 * * \\
(0.008)\end{array}$ & $\begin{array}{l}-0.027 * * * \\
(0.004)\end{array}$ & $\begin{array}{l}-0.025^{* *} \\
(0.004)\end{array}$ & - & $\begin{array}{l}- \\
-\end{array}$ \\
\hline Tangibility $_{(t)}$ & + & $\begin{array}{l}0.155 * * \\
(0.081)\end{array}$ & $\begin{array}{l}0.178 * * * \\
(0.055)\end{array}$ & $\begin{array}{l}0.149 * \\
(0.084)\end{array}$ & $\begin{array}{l}0.173 * * * \\
(0.056)\end{array}$ & $\begin{array}{l}0.179 * * \\
(0.079)\end{array}$ & $\begin{array}{l}0.190 * * * \\
(0.057)\end{array}$ \\
\hline Non-debt tax $\operatorname{shields}_{(t)}$ & - & $\begin{array}{l}0.101 \\
(0.413)\end{array}$ & $\begin{array}{l}-0.157 \\
(0.277)\end{array}$ & $\begin{array}{l}0.125 \\
(0.424)\end{array}$ & $\begin{array}{l}-0.137 \\
(0.279)\end{array}$ & $\begin{array}{l}-0.027 \\
(0.412)\end{array}$ & $\begin{array}{l}-0.219 \\
(0.277)\end{array}$ \\
\hline $\operatorname{Profitability}_{(t)}$ & $+/-$ & $\begin{array}{l}-0.121^{* * *} \\
(0.024)\end{array}$ & $\begin{array}{l}-0.130 * * * \\
(0.019)\end{array}$ & $\begin{array}{l}-0.121 * * * \\
(0.025)\end{array}$ & $\begin{array}{l}-0.130 * * * \\
(0.019)\end{array}$ & $\begin{array}{l}-0.125^{* * *} \\
(0.024)\end{array}$ & $\begin{array}{l}-0.132 * * * \\
(0.019)\end{array}$ \\
\hline $\operatorname{Size}_{(t)}$ & + & $\begin{array}{l}0.003 \\
(0.030)\end{array}$ & $\begin{array}{l}0.014 \\
(0.016)\end{array}$ & $\begin{array}{l}0.002 \\
(0.030)\end{array}$ & $\begin{array}{l}0.014 \\
(0.016)\end{array}$ & $\begin{array}{l}0.014 \\
(0.031)\end{array}$ & $\begin{array}{l}0.019 \\
(0.017)\end{array}$ \\
\hline Estimators & & $I V$ & $G M M$ & $I V$ & $G M M$ & $I V$ & $G M M$ \\
\hline First differences & & Yes & Yes & Yes & Yes & Yes & Yes \\
\hline Number of observations & & 2814 & 2814 & 2814 & 2814 & 2814 & 2814 \\
\hline RSS & & 100.012 & 65.49 & 101.905 & 65.87 & 85.759 & 63.042 \\
\hline AR(1) test & & $-3.87 * * *$ & $-5.74 * * *$ & $-3.80 * * *$ & $-5.70 * * *$ & $-3.98 * * *$ & $-5.76 * * *$ \\
\hline $\operatorname{AR}(2)$ test & & $-1.87 *$ & $-1.73^{*}$ & $-1.87^{*}$ & $-1.75^{*}$ & $-1.73^{*}$ & $-1.66^{*}$ \\
\hline Sargan test & & $7.94(6)$ & $30.74(26)$ & $7.81(6)$ & $30.60(26)$ & $9.64(6)$ & $32.67(26)$ \\
\hline
\end{tabular}

Notes:

This table reports the estimation results from the regression of leverage on lagged leverage, debt maturity, growth opportunities, debt maturity interacted with growth opportunities and the control variables based on Equation (1). See Table A1 for variable definitions. The results are estimated using a two-stage procedure; the results in the first stage used to generate the estimated values of debt maturity are not reported. Columns (1), (3) and (5) adopt the IV estimation method, using the secondlagged leverage as an instrument for the first-lagged leverage. Columns (2), (4) and (6) adopt the twostep GMM estimation method, using from the third-lagged leverage to sixth-lagged leverage as instruments for the first-lagged leverage. The instruments for debt maturity include asset maturity and term structure. Lagged control variables are also included as instruments to yield better fit. Year dummies are not included in any models. $A R(1)$ and $A R(2)$ are tests for first-order and second-order serial correlation, asymptotically distributed as $N(0,1)$ under the null of no first-order and second-order serial correlation, respectively; and Sargan test is a test for over-identifying restrictions, asymptotically distributed as $\chi^{2}$, under the null of valid instruments. Standard errors of coefficients are reported in parenthesis. * ** and $* * *$ indicate the coefficient significant at $10 \%, 5 \%$ and $1 \%$ levels, respectively. 
Table 3

Regression Results for the Debt Maturity Equation

\begin{tabular}{|c|c|c|c|c|c|c|c|}
\hline \multicolumn{8}{|c|}{ Dependent variable: Debt Maturity } \\
\hline $\begin{array}{c}\text { Independent } \\
\text { variable }\end{array}$ & $\begin{array}{l}\text { Exp } \\
\text { Sign }\end{array}$ & (1) & (2) & (3) & (4) & (5) & (6) \\
\hline $\operatorname{Maturity}_{(t-1)}$ & + & $\begin{array}{l}0.386 * * * \\
(0.047)\end{array}$ & $\begin{array}{l}0.407 * * * \\
(0.046)\end{array}$ & $\begin{array}{l}0.387 * * * \\
(0.047)\end{array}$ & $\begin{array}{l}0.408 * * * \\
(0.046)\end{array}$ & $\begin{array}{l}0.383 * * * \\
(0.047)\end{array}$ & $\begin{array}{l}0.405 * * * \\
(0.045)\end{array}$ \\
\hline Leverage $_{(t)}$ & $+/-$ & $\begin{array}{l}0.351 * \\
(0.206)\end{array}$ & $\begin{array}{l}0.511 * * * \\
(0.156)\end{array}$ & $\begin{array}{l}0.355 \\
(0.233)\end{array}$ & $\begin{array}{l}0.529 * * * \\
(0.174)\end{array}$ & $\begin{array}{l}0.312 * \\
(0.190)\end{array}$ & $\begin{array}{l}0.453 * * * \\
(0.144)\end{array}$ \\
\hline${\text { Leverage } \times \text { Growth }_{(t)}}_{(t)}$ & - & $\begin{array}{l}0.027 \\
(0.066)\end{array}$ & $\begin{array}{l}0.025 \\
(0.059)\end{array}$ & $\begin{array}{l}- \\
-\end{array}$ & $\begin{array}{l}- \\
-\end{array}$ & $\begin{array}{l}0.053 \\
(0.057)\end{array}$ & $\begin{array}{l}0.061 \\
(0.051)\end{array}$ \\
\hline $\operatorname{Growth}_{(t)}$ & - & $\begin{array}{l}0.013 \\
(0.009)\end{array}$ & $\begin{array}{l}0.016 * \\
(0.009)\end{array}$ & $\begin{array}{l}0.015^{*} \\
(0.009)\end{array}$ & $\begin{array}{l}0.019 * * \\
(0.008)\end{array}$ & $\begin{array}{l}- \\
-\end{array}$ & $\begin{array}{l}- \\
-\end{array}$ \\
\hline $\operatorname{Size}_{(t)}$ & + & $\begin{array}{l}0.083 * * * \\
(0.018)\end{array}$ & $\begin{array}{l}0.076 * * * \\
(0.018)\end{array}$ & $\begin{array}{l}0.080 * * * \\
(0.019)\end{array}$ & $\begin{array}{l}0.073 * * * \\
(0.018)\end{array}$ & $\begin{array}{l}0.077 * * * \\
(0.019)\end{array}$ & $\begin{array}{l}0.070 * * * \\
(0.019)\end{array}$ \\
\hline Maturity of assets $(t)$ & + & $\begin{array}{l}0.008 \\
(0.006)\end{array}$ & $\begin{array}{l}0.009 \\
(0.006)\end{array}$ & $\begin{array}{l}0.008 \\
(0.006)\end{array}$ & $\begin{array}{l}0.009 \\
(0.006)\end{array}$ & $\begin{array}{l}0.009 \\
(0.006)\end{array}$ & $\begin{array}{l}0.010 \\
(0.006)\end{array}$ \\
\hline $\operatorname{Tax}_{\operatorname{ratio}_{(t)}}$ & $+/-$ & $\begin{array}{l}0.000 * * * \\
(0.000)\end{array}$ & $\begin{array}{l}0.001 * * * \\
(0.000)\end{array}$ & $\begin{array}{l}0.000 * * * \\
(0.000)\end{array}$ & $\begin{array}{l}0.001 * * * \\
(0.000)\end{array}$ & $\begin{array}{l}0.000 * * * \\
(0.000)\end{array}$ & $\begin{array}{l}0.001 * * * \\
(0.000)\end{array}$ \\
\hline Term $_{\text {structure }}(t)$ & + & $\begin{array}{l}-0.002 \\
(0.006)\end{array}$ & $\begin{array}{l}-0.001 \\
(0.006)\end{array}$ & $\begin{array}{l}-0.002 \\
(0.006)\end{array}$ & $\begin{array}{l}-0.001 \\
(0.006)\end{array}$ & $\begin{array}{l}-0.002 \\
(0.006)\end{array}$ & $\begin{array}{l}-0.001 \\
(0.006)\end{array}$ \\
\hline Volatility $_{(t)}$ & - & $\begin{array}{l}0.000 \\
(0.001)\end{array}$ & $\begin{array}{l}0.001 \\
(0.001)\end{array}$ & $\begin{array}{l}0.000 \\
(0.001)\end{array}$ & $\begin{array}{l}0.001 \\
(0.001)\end{array}$ & $\begin{array}{l}0.000 \\
(0.001)\end{array}$ & $\begin{array}{l}0.001 \\
(0.001)\end{array}$ \\
\hline Quality $_{(t)}$ & - & $\begin{array}{l}0.128 \\
(0.097) \\
\end{array}$ & $\begin{array}{l}0.186 * * \\
(0.092) \\
\end{array}$ & $\begin{array}{l}0.130 \\
(0.100) \\
\end{array}$ & $\begin{array}{l}0.190 * * \\
(0.095) \\
\end{array}$ & $\begin{array}{l}0.121 \\
(0.095) \\
\end{array}$ & $\begin{array}{l}0.175^{* *} \\
(0.089) \\
\end{array}$ \\
\hline Estimators & & $I V$ & $G M M$ & $I V$ & $G M M$ & $I V$ & $G M M$ \\
\hline First differences & & Yes & Yes & Yes & Yes & Yes & Yes \\
\hline Number of observations & & 2762 & 2762 & 2762 & 2762 & 2762 & 2762 \\
\hline RSS & & 261.982 & 272.286 & 262.415 & 273.164 & 260.843 & 270.184 \\
\hline$\overline{A R(1) ~ t e s t ~}$ & & $-11.63 * * *$ & $-10.20 * * *$ & $-11.61 * * *$ & $-10.21 * * *$ & $-11.69 * * *$ & $-10.23 * * *$ \\
\hline $\mathbf{A R}(2)$ test & & -0.317 & -0.223 & -0.296 & -0.210 & -0.283 & -0.179 \\
\hline Sargan test & & $3.638(3)$ & $18.33(19)$ & $3.734(2)$ & $18.22(19)$ & $3.471(2)$ & 18.81(19) \\
\hline
\end{tabular}

Notes:

This table reports the estimation results from the regression of debt maturity on lagged debt maturity, leverage, growth opportunities, leverage interacted with growth opportunities and the control variables based on Equation (2). See Table A1 for variable definitions. Columns (1), (3) and (5) adopt the IV estimation method, using the second-lagged debt maturity as an instrument for the first-lagged debt maturity. Columns (2), (4) and (6) adopt the two-step GMM estimation method, using from the thirdlagged debt maturity to fifth-lagged debt maturity as instruments for the first-lagged debt maturity. The instruments for leverage include non-debt tax shields, tangibility and profitability, all in levels. Year dummies are not included in any models. Standard errors of coefficients are reported in parenthesis. *, $* *$ and $* * *$ indicate the coefficient significant at $10 \%, 5 \%$ and $1 \%$ levels, respectively. See Table 2 for notes on test statistics. 
Table 4. Regression Results for the Investment Equation

\begin{tabular}{|c|c|c|c|c|c|c|c|c|c|}
\hline \multicolumn{10}{|c|}{ Dependent variable: Investment } \\
\hline Independent variable & Exp sign & (1) & (2) & (3) & (4) & (5) & (6) & (7) & (8) \\
\hline \multirow{2}{*}{ Investment $_{(t-1)}$} & + & $0.178 * *$ & $0.112 * *$ & $0.286 * * *$ & $0.249 * * *$ & $0.185^{* *}$ & $0.105^{*}$ & $0.224 * * *$ & $0.238 * * *$ \\
\hline & & $(0.088)$ & $(0.055)$ & $(0.094)$ & $(0.073)$ & $(0.078)$ & $(0.061)$ & $(0.086)$ & $(0.064)$ \\
\hline \multirow{2}{*}{ Leverage $_{(t-1)}$} & - & $-2.409 * * *$ & $-2.072 * * *$ & - & - & $-3.179 * * *$ & $-2.403 * * *$ & - & - \\
\hline & & $(0.662)$ & $(0.495)$ & - & - & $(1.015)$ & $(0.829)$ & - & - \\
\hline \multirow{2}{*}{ Leverage $\times$ Growth $_{(t-1)}$} & - & -0.255 & -0.192 & 0.088 & 0.089 & $-0.471^{*}$ & -0.269 & - & - \\
\hline & & $(0.235)$ & $(0.197)$ & $(0.126)$ & $(0.123)$ & $(0.254)$ & $(0.186)$ & - & - \\
\hline \multirow[t]{2}{*}{ Maturity $_{(t-1)}$} & - & -0.002 & 0.059 & - & - & - & - & 0.477 & -0.486 \\
\hline & & $(0.789)$ & $(0.323)$ & - & - & - & - & $(0.753)$ & $(0.633)$ \\
\hline \multirow[t]{2}{*}{${\text { Maturity } \times \text { Growth }_{(t-1)}}$} & - & $-0.190 * * *$ & $-0.128 * *$ & $-0.179 * *$ & $-0.152 * *$ & - & - & $-0.164 * * *$ & $-0.140 * * *$ \\
\hline & & $(0.060)$ & $(0.060)$ & $(0.056)$ & $(0.050)$ & - & - & $(0.051)$ & $(0.045)$ \\
\hline \multirow[t]{2}{*}{$\operatorname{Growth}_{(t-1)}$} & + & $0.117 * * *$ & $0.079 * * *$ & $0.119 * * *$ & $0.100 * * *$ & 0.038 & 0.015 & $0.113 * * *$ & $0.102 * * *$ \\
\hline & & $(0.023)$ & $(0.027)$ & $(0.031)$ & $(0.025)$ & $(0.025)$ & $(0.018)$ & $(0.029)$ & $(0.025)$ \\
\hline \multirow[t]{2}{*}{$\operatorname{Cash}_{\operatorname{flow}}^{(t-1)}$} & + & -0.161 & -0.078 & $0.268 * *$ & $0.282 * * *$ & -0.435 & -0.275 & 0.198 & $0.271 * *$ \\
\hline & & $(0.198)$ & $(0.149)$ & $(0.105)$ & $(0.098)$ & $(0.279)$ & $(0.247)$ & $(0.124)$ & $(0.123)$ \\
\hline Estimators & & $I V$ & $G M M$ & $I V$ & $G M M$ & $I V$ & $G M M$ & $I V$ & $G M M$ \\
\hline First differences & & Yes & Yes & Yes & Yes & Yes & Yes & Yes & Yes \\
\hline Number of observations & & 1456 & 1456 & 2136 & 2136 & 2136 & 2136 & 2136 & 2136 \\
\hline RSS & & 586.461 & 534.637 & 749.768 & 725.887 & 924.788 & 776.096 & 754.758 & 743.131 \\
\hline$\overline{A R(1) ~ t e s t ~}$ & & $-2.77 * * *$ & $-2.58 * * *$ & $-4.84 * * *$ & $-4.18 * * *$ & $-4.54 * * *$ & $-4.11 * * *$ & -4.33 & $-4.39 * * *$ \\
\hline $\mathbf{A R}(2)$ test & & -0.46 & -0.57 & 0.47 & 0.14 & -0.59 & -0.83 & -0.25 & -0.13 \\
\hline Sargan test & & $17.45(14)$ & $31.52(27)$ & - & $15.70(14)$ & $3.87(3)$ & $20.39(17)$ & $4.40(3)$ & $19.87(17)$ \\
\hline
\end{tabular}

\section{Notes:}

This table reports the results from the regression of investment on leverage, debt maturity, their interaction terms with growth opportunities and the control variables based on Equation (3). See Table A1 for variable definitions, Table 2 for notes on test statistics and instruments for debt maturity and leverage. Columns (1), (3), (5) and (7) adopt the IV estimation method, using the second-lagged investment as the instrumental variable for the first-lagged investment. Columns (2), (4), (6) and

(8) adopt the two-step GMM estimation method, using from the third-lagged investment to fifth-lagged investment as instruments for the first-lagged investment. Year dummies are not included in any models. Standard errors of coefficients are reported in parenthesis. $*, * *$ and $* * *$ indicate the coefficient significant at $10 \%$, $5 \%$ and $1 \%$ levels, respectively. 
Table 5

High-Growth versus Low-Growth Firms - Leverage Equation

\begin{tabular}{|c|c|c|c|c|c|}
\hline \multicolumn{6}{|l|}{ Dependent variable: Leverage } \\
\hline Independent variable & $\begin{array}{c}\text { Expected } \\
\text { sign }\end{array}$ & (1) & (2) & (3) & (4) \\
\hline Leverage $_{(t-1)}$ & + & $\begin{array}{l}0.188 * * * \\
(0.095)\end{array}$ & $\begin{array}{l}0.223 * * * \\
(0.071)\end{array}$ & $\begin{array}{l}0.185^{* *} \\
(0.097)\end{array}$ & $\begin{array}{l}0.211 * * * \\
(0.073)\end{array}$ \\
\hline Maturity $_{(t)}$ & $+/-$ & $\begin{array}{l}0.496^{*} \\
(0.295)\end{array}$ & $\begin{array}{l}0.330 * * \\
(0.145)\end{array}$ & $\begin{array}{l}0.512 * \\
(0.305)\end{array}$ & $\begin{array}{l}0.345^{* *} \\
(0.145)\end{array}$ \\
\hline${\text { Maturity } \times \text { Growth }_{(t)}}$ & - & $\begin{array}{l}-0.013 \\
(0.013)\end{array}$ & $\begin{array}{l}-0.014 \\
(0.010)\end{array}$ & - & $\begin{array}{l}- \\
-\end{array}$ \\
\hline $\operatorname{Growth}_{(t)}$ & - & $\begin{array}{l}0.031 * * * \\
(0.010)\end{array}$ & $\begin{array}{l}0.035^{* * *} * \\
(0.009)\end{array}$ & $\begin{array}{l}0.023 * * \\
(0.009)\end{array}$ & $\begin{array}{l}0.028 * * * \\
(0.008)\end{array}$ \\
\hline Growth $_{\times}$High growth dummy $(t)$ & - & $\begin{array}{l}-0.047 * * * \\
(0.008)\end{array}$ & $\begin{array}{l}-0.049 * * * \\
(0.006)\end{array}$ & $\begin{array}{l}-0.047 * * * \\
(0.008)\end{array}$ & $\begin{array}{l}-0.049 * * * \\
(0.007)\end{array}$ \\
\hline $\operatorname{Tangibility}_{(t)}$ & + & $\begin{array}{l}0.163 * * \\
(0.080)\end{array}$ & $\begin{array}{l}0.180 * * * \\
(0.053)\end{array}$ & $\begin{array}{l}0.155^{*} \\
(0.083)\end{array}$ & $\begin{array}{l}0.167 * * * \\
(0.056)\end{array}$ \\
\hline Non-debt tax shields $(t)$ & - & $\begin{array}{l}0.117 \\
(0.400)\end{array}$ & $\begin{array}{l}-0.140 \\
(0.268)\end{array}$ & $\begin{array}{l}0.147 \\
(0.413)\end{array}$ & $\begin{array}{l}-0.076 \\
(0.270)\end{array}$ \\
\hline $\operatorname{Profitability}_{(t)}$ & $+/-$ & $\begin{array}{l}-0.118 * * * \\
(0.024)\end{array}$ & $\begin{array}{l}-0.124 * * * \\
(0.018)\end{array}$ & $\begin{array}{l}-0.118 * * * \\
(0.024)\end{array}$ & $\begin{array}{l}-0.124 * * * \\
(0.018)\end{array}$ \\
\hline $\operatorname{Size}_{(t)}$ & + & $\begin{array}{l}0.005 \\
(0.031) \\
\end{array}$ & $\begin{array}{l}0.011 \\
(0.016) \\
\end{array}$ & $\begin{array}{l}0.004 \\
(0.031) \\
\end{array}$ & $\begin{array}{l}0.011 \\
(0.016) \\
\end{array}$ \\
\hline Estimators & & $I V$ & $G M M$ & $I V$ & $G M M$ \\
\hline First differences & & Yes & Yes & Yes & Yes \\
\hline Number of observations & & 2814 & 2814 & 2814 & 2814 \\
\hline RSS & & 84.722 & 60.087 & 87.846 & 61.650 \\
\hline$\overline{A R(1) ~ t e s t ~}$ & & $-3.59 * * *$ & $-5.42 * * *$ & $-3.48 * * *$ & $-5.37 * * *$ \\
\hline $\mathbf{A R}(2)$ test & & $-1.84 *$ & $-1.81^{*}$ & $-1.84 *$ & $-1.87 *$ \\
\hline Sargan test & & $8.22(6)$ & $27.59(26)$ & $7.84(6)$ & $28.37(26)$ \\
\hline
\end{tabular}

Notes:

This table reports the estimation results from the regression of leverage on lagged leverage, debt maturity, growth opportunities, debt maturity interacted with growth opportunities and the control variables based on Equation (1). The model is augmented by the inclusion of an interaction term between growth opportunities and a high-growth dummy variable. High-growth dummy is equal to 1 if growth is larger than median growth; otherwise, it is equal to 0. See Table A1 for variable definitions. Columns (1) and (3) adopt the IV estimation method, using the second-lagged leverage as an instrumental variable for the first-lagged leverage. Columns (2) and (4) adopt the two-step GMM estimation method, using from the third-lagged leverage to sixth-lagged leverage as instruments for the first-lagged leverage. The instruments for debt maturity include asset maturity and term structure. Year dummies are not included in any models. Standard errors of coefficients are reported in parenthesis. *, $* *$ and $* * *$ indicate the coefficient significant at $10 \%, 5 \%$ and $1 \%$ levels, respectively. See Table 2 for notes on test statistics. 
Table 6

High-Growth versus Low-Growth Firms - Debt Maturity Equation

\begin{tabular}{|c|c|c|c|c|c|}
\hline \multicolumn{6}{|l|}{ Dependent variable: Debt maturity } \\
\hline Independent variable & $\begin{array}{c}\text { Expected } \\
\text { sign } \\
\end{array}$ & (1) & (2) & (3) & (4) \\
\hline Maturity $_{(t-1)}$ & + & $\begin{array}{l}0.386^{* * *} \\
(0.047)\end{array}$ & $\begin{array}{l}0.408 * * * \\
(0.046)\end{array}$ & $\begin{array}{l}0.387 * * * \\
(0.047)\end{array}$ & $\begin{array}{l}0.408 * * * \\
(0.046)\end{array}$ \\
\hline Leverage $_{(t)}$ & $+/-$ & $\begin{array}{l}0.361 * \\
(0.211)\end{array}$ & $\begin{array}{l}0.510^{* * *} \\
(0.161)\end{array}$ & $\begin{array}{l}0.328 * \\
(0.203)\end{array}$ & $\begin{array}{l}0.489 * * * \\
(0.161)\end{array}$ \\
\hline Leverage $\times$ Growth $_{(t)}$ & - & $\begin{array}{l}0.025 \\
(0.065)\end{array}$ & $\begin{array}{l}0.023 \\
(0.059)\end{array}$ & $\begin{array}{l}- \\
-\end{array}$ & $\begin{array}{l}- \\
-\end{array}$ \\
\hline $\operatorname{Growth}_{(t)}$ & - & $\begin{array}{l}-0.002 \\
(0.017)\end{array}$ & $\begin{array}{l}-0.002 \\
(0.017)\end{array}$ & $\begin{array}{l}0.0006 \\
(0.017)\end{array}$ & $\begin{array}{l}0.0002 \\
(0.017)\end{array}$ \\
\hline Growth $_{\times}$High growth dummy $_{(t)}$ & - & $\begin{array}{l}0.014 \\
(0.016)\end{array}$ & $\begin{array}{l}0.017 \\
(0.016)\end{array}$ & $\begin{array}{l}0.013 \\
(0.016)\end{array}$ & $\begin{array}{l}0.017 \\
(0.016)\end{array}$ \\
\hline $\operatorname{Size}_{(t)}$ & + & $\begin{array}{l}0.083 * * * \\
(0.019)\end{array}$ & $\begin{array}{l}0.076^{* * *} \\
(0.018)\end{array}$ & $\begin{array}{l}0.082 * * * \\
(0.018)\end{array}$ & $\begin{array}{l}0.074 * * * \\
(0.018)\end{array}$ \\
\hline Maturity of assets $(t)$ & + & $\begin{array}{l}0.008 \\
(0.006)\end{array}$ & $\begin{array}{l}0.009 \\
(0.006)\end{array}$ & $\begin{array}{l}0.009 \\
(0.006)\end{array}$ & $\begin{array}{l}0.009 \\
(0.006)\end{array}$ \\
\hline $\operatorname{Tax}_{\text {ratio }_{(}(t)}$ & $+/-$ & $\begin{array}{l}0.001 * * * \\
(0.000)\end{array}$ & $\begin{array}{l}0.001 * * * \\
(0.000)\end{array}$ & $\begin{array}{l}0.001 * * * \\
(0.000)\end{array}$ & $\begin{array}{l}0.001 * * * \\
(0.000)\end{array}$ \\
\hline Term $_{\text {structure }}(t)$ & + & $\begin{array}{l}-0.002 \\
(0.006)\end{array}$ & $\begin{array}{l}-0.001 \\
(0.006)\end{array}$ & $\begin{array}{l}-0.002 \\
(0.006)\end{array}$ & $\begin{array}{l}-0.001 \\
(0.006)\end{array}$ \\
\hline Volatility $_{(t)}$ & - & $\begin{array}{l}0.000 \\
(0.001)\end{array}$ & $\begin{array}{l}0.001 \\
(0.001)\end{array}$ & $\begin{array}{l}0.000 \\
(0.001)\end{array}$ & $\begin{array}{l}0.001 \\
(0.001)\end{array}$ \\
\hline Quality $_{(t)}$ & - & $\begin{array}{l}0.125 \\
(0.097)\end{array}$ & $\begin{array}{l}0.180 * * \\
(0.092)\end{array}$ & $\begin{array}{l}0.120 \\
(0.097) \\
\end{array}$ & $\begin{array}{l}0.177 * * \\
(0.091)\end{array}$ \\
\hline Estimators & & $I V$ & $G M M$ & $I V$ & $G M M$ \\
\hline First differences & & Yes & Yes & Yes & Yes \\
\hline Number of observations & & 2762 & 2762 & 2762 & 2762 \\
\hline RSS & & 261.97 & 272.11 & 261.48 & 271.55 \\
\hline$\overline{\operatorname{AR}(1) \text { test }}$ & & $-11.65 * * *$ & $-10.21 * * *$ & $-11.66 * * *$ & $-10.22 * * *$ \\
\hline $\operatorname{AR}(2)$ test & & -0.30 & -0.20 & -0.28 & -0.18 \\
\hline Sargan test & & $3.60(2)$ & $18.84(19)$ & $3.79(3)$ & $19.10(20)$ \\
\hline
\end{tabular}

Notes:

This table reports the estimation results from the regression of debt maturity on lagged debt maturity, leverage, growth opportunities, leverage interacted with growth opportunities and the control variables based on Equation (2). The model is augmented by the inclusion of an interaction term between growth opportunities and a high-growth dummy variable. High-growth dummy is equal to 1 if growth is larger than median growth; otherwise, it is equal to 0. See Table A1 for variable definitions. Columns (1) and (3) adopt the IV estimation method, using the second-lagged maturity as an instrumental variable for the first-lagged maturity. Columns (2) and (4) adopt the two-step GMM estimation method, using from the third-lagged maturity to fifth-lagged maturity as instruments for the first-lagged maturity. The instruments for leverage include non-debt tax shields, tangibility and profitability, all in levels. Year dummies are not included in any models. Standard errors of coefficients are reported in parenthesis. *, $* *$ and $* * *$ indicate the coefficient significant at $10 \%, 5 \%$ and $1 \%$ levels, respectively. See Table 2 for notes on test statistics. 
Table 7

High-Growth versus Low-Growth Firms - Investment Equation

\begin{tabular}{|c|c|c|c|c|}
\hline \multicolumn{5}{|l|}{ Dependent variable: Investment } \\
\hline Independent variable & Expected sign & (1) & (2) & (3) \\
\hline Investment $_{(t-1)}$ & + & $\begin{array}{l}0.108 * * \\
(0.053)\end{array}$ & $\begin{array}{l}0.119 * * \\
(0.052)\end{array}$ & $\begin{array}{l}0.116 * * \\
(0.053)\end{array}$ \\
\hline Leverage $_{(t-1)}$ & - & $\begin{array}{l}-1.96 * * * \\
(0.438)\end{array}$ & $\begin{array}{l}-2.043 * * * \\
(0.512)\end{array}$ & $\begin{array}{l}-1.936 * * * \\
(0.459)\end{array}$ \\
\hline Leverage $\times$ Growth $_{(t-1)}$ & - & $\begin{array}{l}-0.286^{*} \\
(0.165)\end{array}$ & $\begin{array}{l}-0.183 \\
(0.207)\end{array}$ & $\begin{array}{l}-0.252 \\
(0.206)\end{array}$ \\
\hline Leverage $\times$ High growth dummy $(t-1)$ & - & $\begin{array}{l}-0.117 \\
(0.112)\end{array}$ & $\begin{array}{l}-0.099 \\
(0.128)\end{array}$ & - \\
\hline Maturity $_{(t-1)}$ & - & $\begin{array}{l}0.102 \\
(0.286)\end{array}$ & $\begin{array}{l}0.045 \\
(0.350)\end{array}$ & $\begin{array}{l}0.073 \\
(0.328)\end{array}$ \\
\hline Maturity $\times$ Growth $_{(t-1)}$ & - & $\begin{array}{l}-0.117 * * * \\
(0.049)\end{array}$ & $\begin{array}{l}-0.133 * * \\
(0.059)\end{array}$ & $\begin{array}{l}-0.126^{* *} \\
(0.052)\end{array}$ \\
\hline Maturity $\times$ High growth dummy ${ }_{(t-1)}$ & - & $\begin{array}{l}0.126 * * * \\
(0.038)\end{array}$ & - & $\begin{array}{l}0.107 * * * \\
(0.033)\end{array}$ \\
\hline $\operatorname{Growth}_{(t-1)}$ & + & $\begin{array}{l}0.084 * * * \\
(0.024)\end{array}$ & $\begin{array}{l}0.082 * * * \\
(0.026)\end{array}$ & $\begin{array}{l}0.087 * * * \\
(0.025)\end{array}$ \\
\hline $\operatorname{Cash}_{\text {flow }}(t-1)$ & + & $\begin{array}{c}-0.078 \\
(0.136) \\
\end{array}$ & $\begin{array}{l}-0.064 \\
(0.155) \\
\end{array}$ & $\begin{array}{c}-0.061 \\
(0.140) \\
\end{array}$ \\
\hline Estimators & & $G M M$ & $G M M$ & $G M M$ \\
\hline First differences & & Yes & Yes & Yes \\
\hline Number of observations & & 1456 & 1456 & 1456 \\
\hline RSS & & 525.51 & 535.63 & 526.73 \\
\hline $\operatorname{AR}(1)$ test & & $-2.56 * *$ & $-2.60 * * *$ & $-2.57 * * *$ \\
\hline $\operatorname{AR}(2)$ test & & -0.47 & -0.51 & -0.42 \\
\hline Sargan test & & $29.08(27)$ & $31.03(27)$ & $28.91(27)$ \\
\hline
\end{tabular}

Notes:

This table reports the results from the regression of investment on leverage, debt maturity, their interaction terms with growth opportunities and the control variables based on Equation (3). The model is augmented by the inclusion of two interaction terms between leverage and debt maturity and a highgrowth dummy variable. High-growth dummy is equal to 1 if growth is larger than median growth; otherwise, it is equal to 0. See Table A1 for variable definitions. All models adopt the two-step GMM estimation method, using from the third-lagged investment to fifth-lagged investment as instruments for the first-lagged investment. The instruments for leverage include non-debt tax shields, tangibility and profitability. The instruments for debt maturity include asset maturity and term structure. Year dummies are not included in any models. Standard errors of coefficients are reported in parenthesis. *, $* *$ and $* * *$ indicate the coefficient significant at $10 \%, 5 \%$ and $1 \%$ levels, respectively. See Table 2 for notes on test statistics. 